\title{
Platelet-Rich Plasma in Facial Rejuvenation: A Systematic Appraisal of the Available Clinical Evidence
}

\author{
Hong Xiao' \\ Dan $X u^{2}$ \\ Rui $\mathrm{Mao}^{3}$ \\ Minqin Xiao' \\ Yang Fang ${ }^{4}$ \\ Yin Liu' \\ 'Department of Plastic Surgery, The \\ Second Affiliated Hospital of Kunming \\ Medical University, Kunming, Yunnan, \\ People's Republic of China; ${ }^{2}$ Department \\ of Dermatology, The First Affiliated \\ Hospital of Kunming Medical University, \\ Kunming, Yunnan, People's Republic of \\ China; ${ }^{3}$ School of Stomatology, Kunming \\ Medical University, Kunming, Yunnan, \\ People's Republic of China; ${ }^{4}$ Wushi Jiamei \\ Beauty Hospital, Kunming, Yunnan, \\ People's Republic of China
}

Correspondence: Yin Liu Department of Plastic Surgery, The Second Affiliated Hospital of Kunming Medical University, No. 374, Dianmian Road, Kunming, Yunnan, 650103, People's Republic of China

Tel +86-I365888 3652

Email liuyinsky@163.com
Purpose: Platelet-rich plasma (PRP) is a promising noninvasive technique for facial rejuvenation. This systematic literature review aims to appraise the nature and quality of published evidence evaluating the effectiveness and safety of PRP in facial rejuvenation.

Patients and Methods: A systematic literature review was conducted with the search string "Platelet-rich plasma AND Facial rejuvenation" in PubMed and Embase. Clinical studies evaluating the outcomes after PRP-based facial rejuvenation either as monotherapy or in combination with other treatment modalities were included. Studies evaluating wound-healing properties of PRP were excluded. The outcomes included both patient-reported and physician-assessed outcomes. Nonstatistical synthesis of evidence was performed by qualitative assessment. The results are reported by the Synthesis Without Meta-analysis (SWiM) reporting standard.

Results: A total of 36 studies that included a total of 3172 patients were considered for the evidence synthesis. The number of patients in the included studies ranging from 11 to 2005 with a median of 27.5 patients that reflects the challenges in clinically assessing the aesthetic outcomes after PRP-based facial rejuvenation. Among the 36 studies, 17 were observational studies and 18 were interventional studies with 1 being case report PRP was evaluated either alone or in combination with hyaluronic acid, lipofilling, micro-needling technique, and laser-based interventions. Among the studies, 1 study reported the enhanced platelet concentrate in a fibrin matrix to be relatively safe and effective with a maximum benefit observed at 12 weeks suggesting the platelet-rich fibrin matrix may provide desired aesthetic outcomes and it requires further studies to substantiate.

Conclusion: The results suggest very limited clinical evidence, and further clinical studies are warranted to establish the effectiveness of PRP in facial rejuvenation. Furthermore, a consensus for end points used for establishing clinical utility in patients requiring facial rejuvenation is warranted.

Keywords: fibrin, hyaluronic acid, platelet-rich plasma, rejuvenation, wound healing

\section{Introduction}

The main purpose of facial rejuvenation is to reverse the aging process either by surgical or noninvasive modalities. ${ }^{1}$ In recent years, despite the increase in the number of facial rejuvenation cosmetic procedures, there is a decrease in the number of patients opting for surgical facial rejuvenation procedures. ${ }^{2}$ This emphasizes the importance of noninvasive procedures in improving cosmetic outcomes. Among the noninvasive facial rejuvenation methods, platelet-rich plasma (PRP), which is a platelet concentrate obtained from autologous plasma, has been used in wide dermatological applications including facial rejuvenation. $^{3}$ 
PRP concentrate consists of various growth factors that perform diverse functions including but not limited to mitogenic and chemotactic functions. The growth factors in PRP include platelet-derived growth factors (PDGFs), transforming growth factor- $\beta 1$ (TGF- $\beta 1$ ), TGF- $\beta 2$, vascular endothelial growth factor (VEGF), basic fibroblast growth factor (bFGF), and epithelial growth factor (EGF). ${ }^{3}$ Although the exact mechanism of action of PRP in bringing about facial rejuvenation is not yet elucidated, it is hypothesized that the growth factors may mediate tissue repair and regulate cellular proliferation and differentiation genes thereby leading to angiogenesis. ${ }^{1}$ These growth factors facilitate rejuvenation at the cellular level, which may lead to better long-term effects in comparison with invasive procedures. ${ }^{4}$ The most suitable PRP preparation method is not yet clear. PRP can be prepared by single and double spin systems. The double spin kits have the potential to yield highly concentrated PRP, while single spin designs result in a serum with less platelets than whole blood (platelet poor plasma). ${ }^{5}$ The use of PRP was further fine-tuned by the introduction of platelet-rich fibrin, which is a modified concentrate of PDGFs extracted from autologous plasma, ${ }^{6}$ and is prepared by procedure similar to PRP preparation. ${ }^{7}$

Despite the availability of different extraction procedures for PRP, there is no consensus on the effectiveness of the extraction procedures. Further, clinically PRP is used both as topical and intradermal injectables. This has further complicated the assessment of effectiveness. Due to the lack of high-quality clinical evidence, the usage of PRP is currently governed by the treating physicians' clinical judgment and discretion. The clinical evidence landscape is also further complicated by the usage of multiple patients- and physician-reported outcomes of qualitative nature. In this context, the main purpose of this systematic literature review is to appraise the available clinical evidence to provide insights and to assist the treating physicians in clinical decision-making.

\section{Methodology}

\section{Data Sources and Searches}

The systematic literature review was performed according to the Synthesis Without Meta-analysis (SWiM) guidelines. PubMed and Embase were searched from inception to September 14, 2021. The search was performed with the keywords "platelet-rich plasma AND facial rejuvenation." A literature search was performed in the databases with a general search string to retrieve all possible studies (clinical trials, observational studies). Additionally, search strings relevant to each query were also used to retrieve any study that could have been missed with a general search string.

\section{Study Selection}

Two reviewers independently screened the abstracts and full texts for eligibility for inclusion. Literature from PubMed and Embase were exported into excel to a single master data document. Reviews, meta-analyses, duplicated publications from the same patient population, in vitro studies, and non-English articles were excluded. Any disagreements regarding study inclusion were resolved by a third independent reviewer. Various study attributes including study design, number of patients, treatment arms, study outcomes, end points, and salient results were extracted for appraisal. The PRISMA guidelines were followed for the development of this review (Figure 1). The qualitative assessment of the included studies was performed by the New Castle Ottawa scale for observational studies and JADAD scale for randomized control studies. The study was prospectively registered on the PROSPERO website (ID:CRD42018112733).

\section{Results}

The systematic search yielded a total of 161 articles that were subjected to preliminary screening based on the title and abstract. A total of 36 studies were included for the evidence synthesis, of which, 18 studies were interventional, whereas 17 were observational studies; the remaining 1 study was a case report. The baseline trial characteristics of the studies included in the analysis are represented in Table 1. Among the 36 studies, 9 (25\%) studies used PRP as monotherapy and 23 (80\%) studies used PRP in combination with other techniques such as micro-needling, $\mathrm{CO}_{2}$ laser treatment, or hyaluronic acid, growth factors, and Botox. PRP was used for treating acne scars in 17 studies $(47.22 \%)$, facial aging in 17 studies (48.44\%), and loss of tissue volume in 2 studies.

Except for 7 studies (19.44\%), all studies reported a significant improvement after PRP application either as monotherapy or combination therapy in various conditions of facial rejuvenation including facial wrinkles, aging, pigmentation, nasolabial folds, acne scars, and tissue volume. 


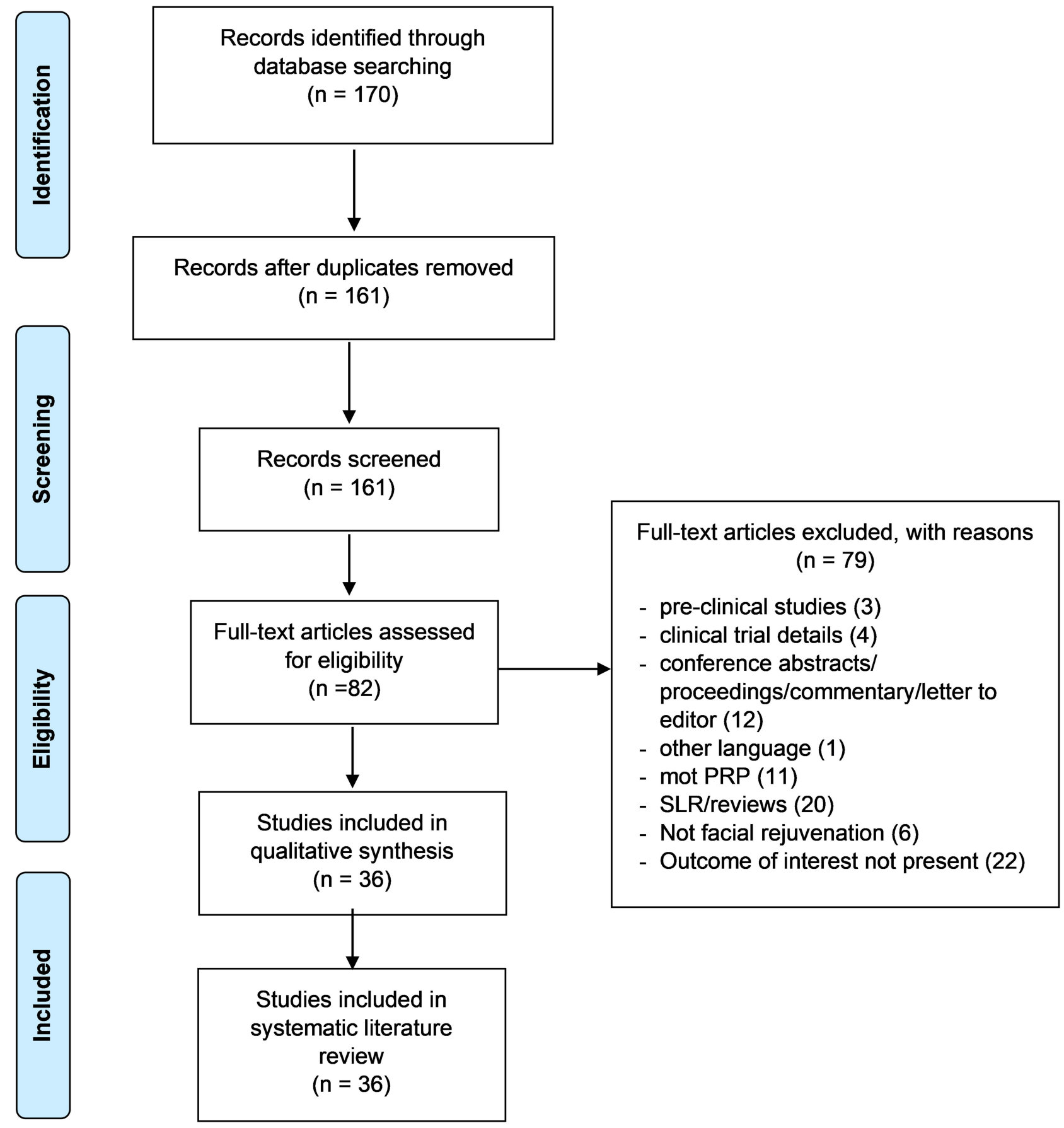

Figure I PRISMA flow chart.

Notes: PRISMA figure adapted from Moher D, Liberati A, Altman D, Tetzlaff J, et al. The PRISMA statement for reporting systematic reviews and meta-analyses of studies that evaluate health care interventions: explanation and elaboration. Journal of clinical epidemiology. 2009;62(I0). Creative Commons. ${ }^{60}$

\section{Administration of PRP}

Due to the non-specific nature of autologous PRP, the dose of administration of PRP is not standardized in clinical practice. Since the active component of PRP is the growth promoters released by the platelets upon activation, it may not be feasible to standardize the same. Among the 36 studies, 20 studies reported the volume of PRP administered in the respective cohort of patients, and it ranged from 0.1 to $4 \mathrm{~mL}$ (Table 2). Although the purpose and desired outcome in each study were different, the rationale for using a particular volume of platelet concentrate was not explained in any of the studies. Further, platelet counts and leukocyte cell counts were provided only in 
Table I Baseline Characteristics of the Included Studies

\begin{tabular}{|c|c|c|c|c|c|}
\hline Authors & $\begin{array}{l}\text { No. of } \\
\text { Patients }\end{array}$ & Therapy & Condition & $\begin{array}{l}\text { Assessment } \\
\text { Period }\end{array}$ & $\begin{array}{l}\text { Mean Agel } \\
\text { Range } \\
\text { (Years) }\end{array}$ \\
\hline Lee $2018^{50}$ & 31 & $\begin{array}{l}\text { PRP } \\
\text { monotherapy }\end{array}$ & Facial aging & 5.7 weeks & $21-80$ \\
\hline $\begin{array}{l}\text { Cameli } \\
2017^{51}\end{array}$ & 12 & $\begin{array}{l}\text { PRP } \\
\text { monotherapy }\end{array}$ & Facial aging & I month & $45-65$ \\
\hline Abuaf $2016^{52}$ & 20 & $\begin{array}{l}\text { PRP } \\
\text { monotherapy }\end{array}$ & Skin aging: sagging, wrinkles, pigmentation & - & $43.65 \pm 2.43$ \\
\hline $\begin{array}{l}\text { Elnehrawy } \\
2017^{53}\end{array}$ & 20 & $\begin{array}{l}\text { PRP } \\
\text { monotherapy }\end{array}$ & $\begin{array}{l}\text { Facial wrinkles [Nasolabial fold (NLFs), crows' feet wrinkles, and } \\
\text { transverse forehead lines] }\end{array}$ & 8 weeks & $36.90 \pm 8.21$ \\
\hline $\begin{array}{l}\text { Gordon } \\
2016^{54}\end{array}$ & I & $\begin{array}{l}\text { PRP } \\
\text { monotherapy }\end{array}$ & $\begin{array}{l}\text { Severe actinic scarring around lips, with generalized loss of lip } \\
\text { volume. In addition, the lip and perioral area presented with sun } \\
\text { damage }\end{array}$ & - & 44 \\
\hline $\begin{array}{l}\text { Yuksel } \\
2014^{44}\end{array}$ & 10 & $\begin{array}{l}\text { PRP } \\
\text { monotherapy }\end{array}$ & Skin aging: sagging, wrinkles, pigmentation & 3 months & $50 \pm 8$ \\
\hline $\begin{array}{l}\text { Mehryan } \\
2014^{55}\end{array}$ & 10 & $\begin{array}{l}\text { PRP } \\
\text { monotherapy }\end{array}$ & Facial aging, infraorbital dark circles, and crow's feet wrinkles & 3 months & 41.2 \\
\hline Kang $2014^{56}$ & 20 & $\begin{array}{l}\text { PRP } \\
\text { monotherapy }\end{array}$ & Facial aging: wrinkles and darkened skin tone & 3 months & $50.6 \pm 3.7$ \\
\hline $\begin{array}{l}\text { Redaelli } \\
2010^{57}\end{array}$ & 23 & $\begin{array}{l}\text { PRP } \\
\text { monotherapy }\end{array}$ & Acne scar, forehead scar, wrinkles & I month & 47 \\
\hline Sevilla $2015^{58}$ & 80 & $\begin{array}{l}\text { PRP } \\
\text { monotherapy }\end{array}$ & Facial folds (nasolabial folds) & I year & $35-65$ \\
\hline $\begin{array}{l}\text { Ibrahim } \\
2018^{13}\end{array}$ & 35 & $\begin{array}{l}\text { Combination } \\
\text { therapy }\end{array}$ & Atrophic post-acne scars & I year & $24.7 \pm 6.8$ \\
\hline $\operatorname{Min} 2018^{15}$ & 25 & $\begin{array}{l}\text { Combination } \\
\text { therapy }\end{array}$ & Acne scars & 28 days & 31.9 \\
\hline $\begin{array}{l}\text { Abdel Aal } \\
2018^{16}\end{array}$ & 30 & $\begin{array}{l}\text { Combination } \\
\text { therapy }\end{array}$ & Acne scars & 6 months & 24.73 \\
\hline $\begin{array}{l}\text { El-Domyati } \\
2018^{11}\end{array}$ & 24 & $\begin{array}{l}\text { Combination } \\
\text { therapy }\end{array}$ & Atrophic acne scars & 3 months & $27.33 \pm 4.05$ \\
\hline \multirow[t]{2}{*}{$\begin{array}{l}\text { Al Taweel } \\
2018^{21}\end{array}$} & \multirow[t]{2}{*}{40} & \multirow[t]{2}{*}{$\begin{array}{l}\text { Combination } \\
\text { therapy }\end{array}$} & \multirow[t]{2}{*}{ Atrophic acne scars } & \multirow[t]{2}{*}{3 months } & $\begin{array}{l}\text { Group A: } \\
28.65 \pm 7.74\end{array}$ \\
\hline & & & & & $\begin{array}{l}\text { Group B: } \\
25.10 \pm 6.70\end{array}$ \\
\hline Tenna $2017^{25}$ & 30 & $\begin{array}{l}\text { Combination } \\
\text { therapy }\end{array}$ & Atrophic acne scars & 6 months & $18-52$ \\
\hline Asif $2016^{12}$ & 50 & $\begin{array}{l}\text { Combination } \\
\text { therapy }\end{array}$ & Atrophic scars & 3 months & 25.72 \\
\hline $\begin{array}{l}\text { Faghihi } \\
2016^{17}\end{array}$ & 16 & $\begin{array}{l}\text { Combination } \\
\text { therapy }\end{array}$ & Atrophic acne scars: & 4 months & 36.8 \\
\hline
\end{tabular}

(Continued) 
Table I (Continued).

\begin{tabular}{|c|c|c|c|c|c|}
\hline Authors & $\begin{array}{l}\text { No. of } \\
\text { Patients }\end{array}$ & Therapy & Condition & $\begin{array}{l}\text { Assessment } \\
\text { Period }\end{array}$ & $\begin{array}{l}\text { Mean Age/ } \\
\text { Range } \\
\text { (Years) }\end{array}$ \\
\hline Zhu $2013^{22}$ & 22 & $\begin{array}{l}\text { Combination } \\
\text { therapy }\end{array}$ & Acne or acne scar & 3 months & 28 \\
\hline Lee $2011^{18}$ & 14 & $\begin{array}{l}\text { Combination } \\
\text { therapy }\end{array}$ & Acne scars & 4 months & 28.1 \\
\hline $\begin{array}{l}\text { El-Domyati } \\
2018^{10}\end{array}$ & 24 & $\begin{array}{l}\text { Combination } \\
\text { therapy }\end{array}$ & Facial wrinkles and other signs of photoaging & 3 months & $50.87 \pm 4.35$ \\
\hline $\begin{array}{l}\text { Deshmukh } \\
2018^{39}\end{array}$ & 40 & $\begin{array}{l}\text { Combination } \\
\text { therapy }\end{array}$ & Atrophic acne scars & 2 months & $\begin{array}{l}26.9 \text { in males } \\
\text { and } 26.7 \text { in } \\
\text { females }\end{array}$ \\
\hline Kar $2017^{20}$ & 30 & $\begin{array}{l}\text { Combination } \\
\text { therapy }\end{array}$ & Atrophic acne scars & I month & $25.06 \pm 4.44$ \\
\hline $\begin{array}{l}\text { Willemsen } \\
2018^{26}\end{array}$ & 32 & $\begin{array}{l}\text { Combination } \\
\text { therapy }\end{array}$ & Loss of skin elasticity and tissue volume & I year & $52 \pm 6.75$ \\
\hline Ali $2018^{32}$ & 63 & $\begin{array}{l}\text { Combination } \\
\text { therapy }\end{array}$ & Facial aging & 24 months & $\begin{array}{l}\text { Female: } 40 \\
\text { male: } 45-55\end{array}$ \\
\hline $\begin{array}{l}\text { Ibrahim } \\
2017^{9}\end{array}$ & 90 & $\begin{array}{l}\text { Combination } \\
\text { therapy }\end{array}$ & $\begin{array}{l}\text { Atrophic post-acne scars, atrophic post-traumatic scars, post } \\
\text { chickenpox scars }\end{array}$ & 3 months & - \\
\hline Ulusal $2017^{35}$ & 94 & $\begin{array}{l}\text { Combination } \\
\text { therapy }\end{array}$ & Facial aging & - & $53.0 \pm 5.6$ \\
\hline Hui $2017^{19}$ & 13 & $\begin{array}{l}\text { Combination } \\
\text { therapy }\end{array}$ & Facial aging & 3 months & $42.08 \pm 7.37$ \\
\hline $\begin{array}{l}\text { Kamakura } \\
2015^{36}\end{array}$ & 2005 & $\begin{array}{l}\text { Combination } \\
\text { therapy }\end{array}$ & Wrinkles and depression in the skin & 3 months & 48.2 \\
\hline $\begin{array}{l}\text { Willemsen } \\
2014^{27}\end{array}$ & 82 & $\begin{array}{l}\text { Combination } \\
\text { therapy }\end{array}$ & $\begin{array}{l}\text { Loss of tissue volume, significant ptosis, and the subsequent } \\
\text { descent of tissues }\end{array}$ & 3 months & $35-65$ \\
\hline $\begin{array}{l}\text { van Dongen } \\
2021^{59}\end{array}$ & 28 & $\begin{array}{l}\text { Combination } \\
\text { therapy }\end{array}$ & Facial aging & I year & - \\
\hline Abdel- & & & Maguid $2021^{37}$ & 33 & $\begin{array}{l}\text { Combination } \\
\text { therapy }\end{array}$ \\
\hline $\begin{array}{l}\text { Atrophic } \\
\text { acne scars } \\
\text { Sasaki } 2019^{30}\end{array}$ & 10 & $\begin{array}{l}\text { Combination } \\
\text { therapy }\end{array}$ & Facial aging & I year & - \\
\hline $\begin{array}{l}\text { El-Taieb } \\
2019^{23}\end{array}$ & 75 & $\begin{array}{l}\text { Combination } \\
\text { therapy }\end{array}$ & Atrophic acne scars & I year & $26 \pm 5.1$ \\
\hline $\begin{array}{l}\text { Rigotti } \\
2016^{28}\end{array}$ & 13 & $\begin{array}{l}\text { Combination } \\
\text { therapy }\end{array}$ & Facial aging & 3 years & - \\
\hline Alam $2018^{14}$ & 27 & $\begin{array}{l}\text { Combination } \\
\text { therapy }\end{array}$ & Facial aging & I year & $46.37 \pm 10.88$ \\
\hline
\end{tabular}

Abbreviation: PRP, platelet-rich plasma. 


\begin{tabular}{|c|c|c|c|}
\hline 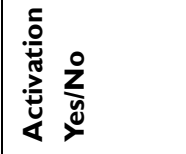 & $\stackrel{\circ}{z}$ & $\stackrel{\circ}{z}$ & \\
\hline 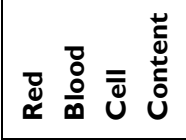 & 1 & ' & \\
\hline 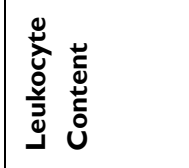 & 1 & 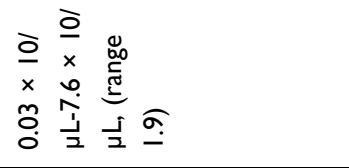 & \\
\hline 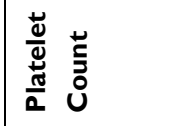 & 1 & 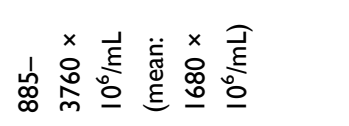 & \\
\hline 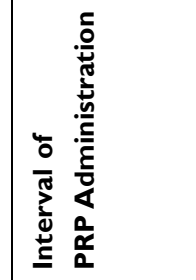 & I & 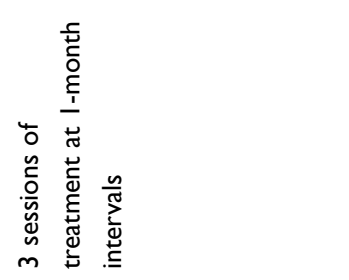 & \\
\hline 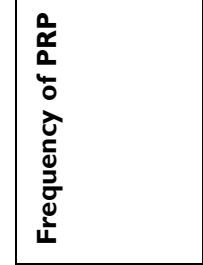 & - & $m$ & - \\
\hline 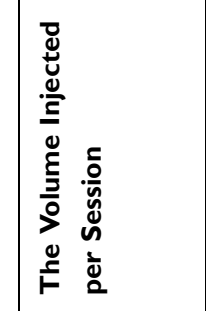 & 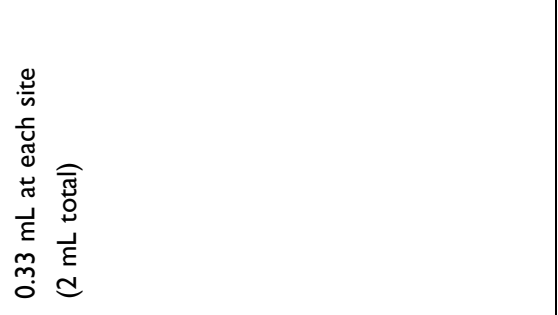 & 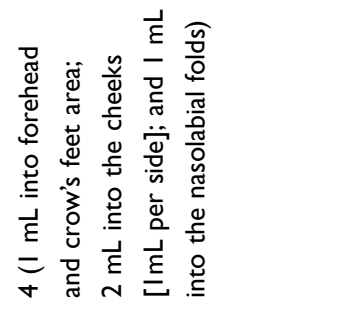 & $\underset{\sim}{\vec{\xi}}$ \\
\hline 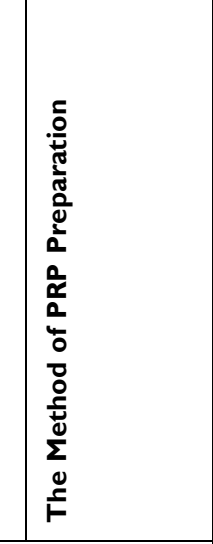 & 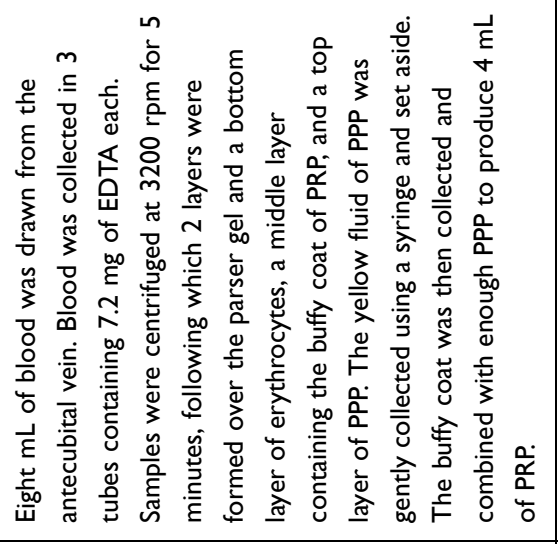 & 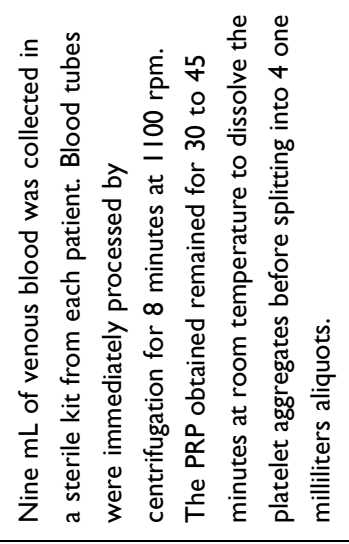 & 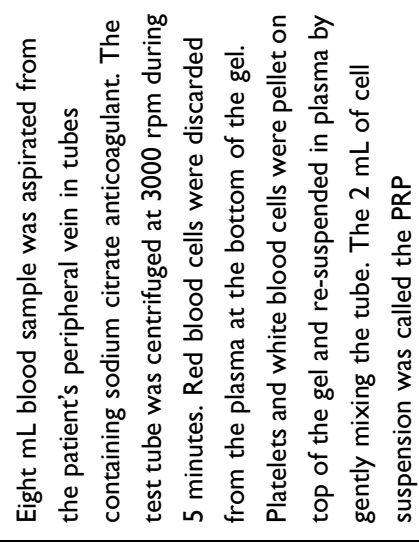 \\
\hline & 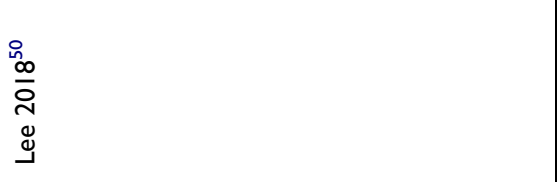 & 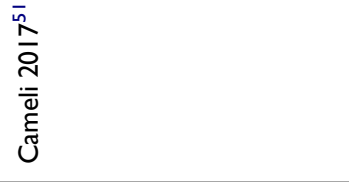 & 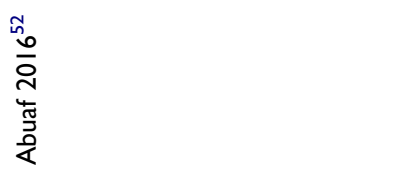 \\
\hline
\end{tabular}




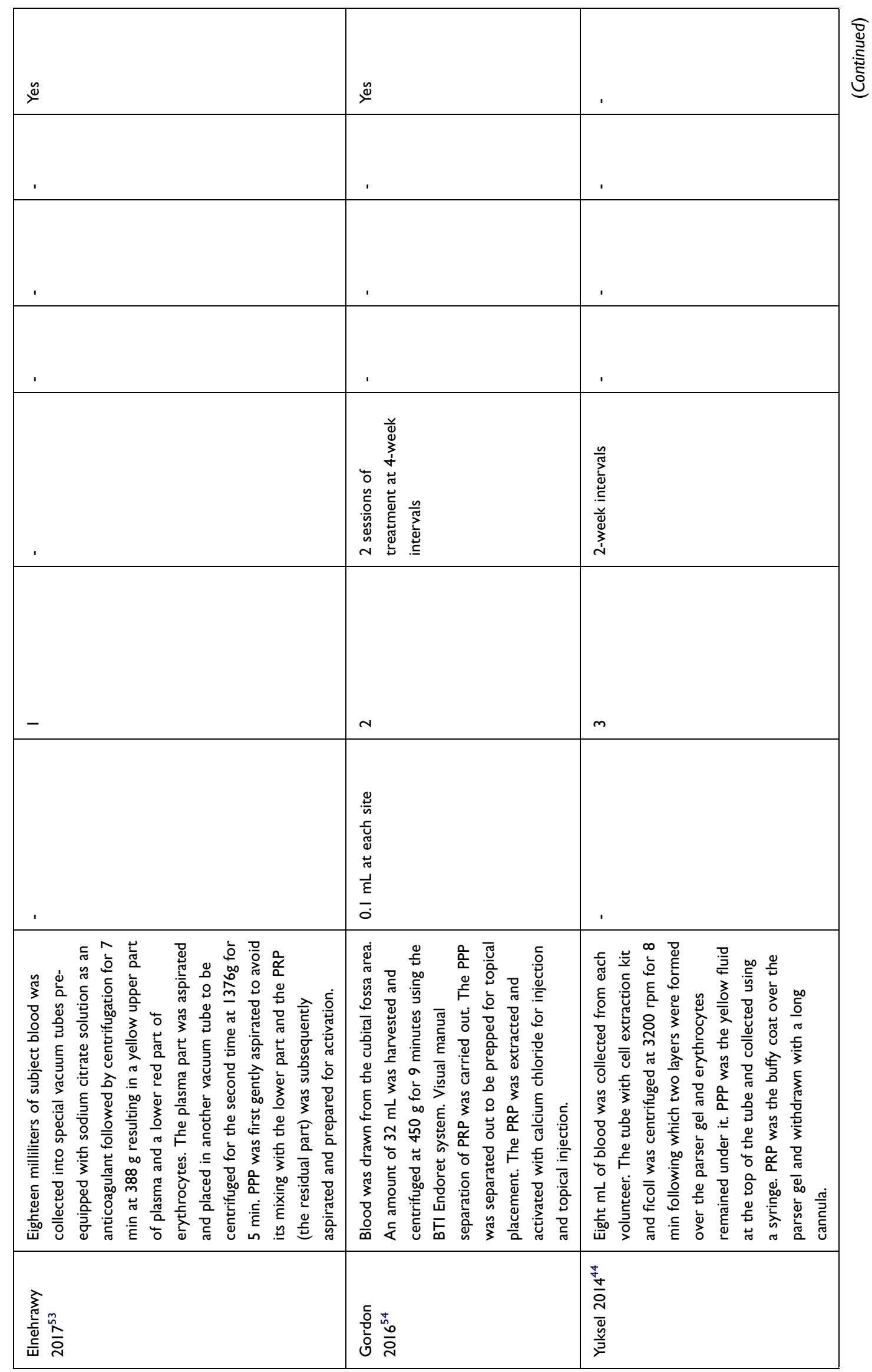




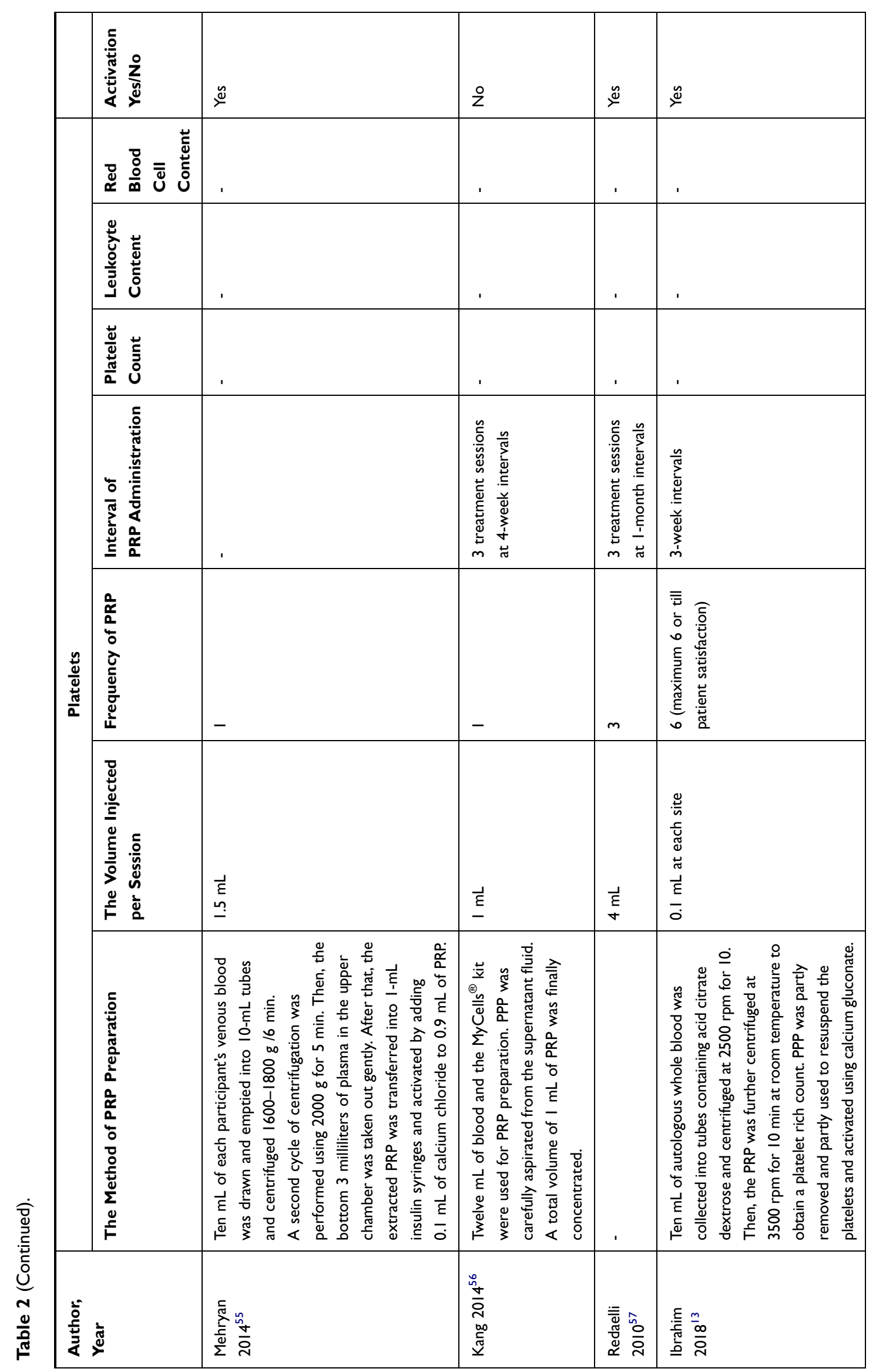




\begin{tabular}{|c|c|c|}
\hline 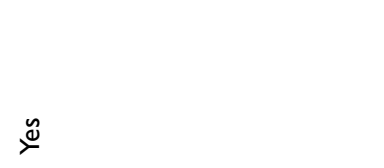 & $\stackrel{\check{\nu}}{\succ}$ & $\stackrel{\check{\varpi}}{\check{\nu}}$ \\
\hline ' & ' & . \\
\hline ' & ' & \\
\hline ' & ' & \\
\hline 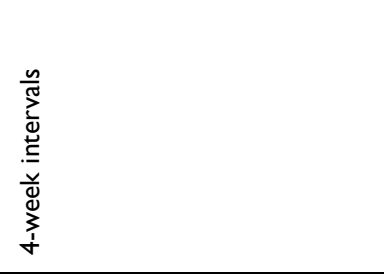 & 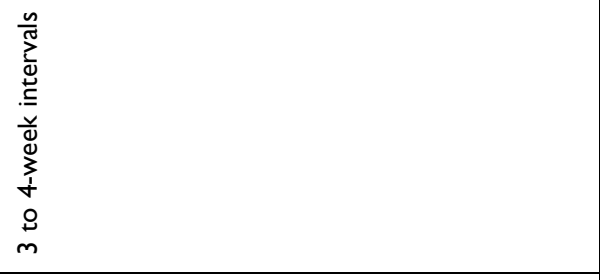 & 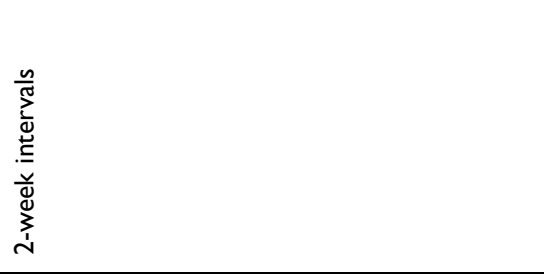 \\
\hline N & $N$ & $\bullet$ \\
\hline 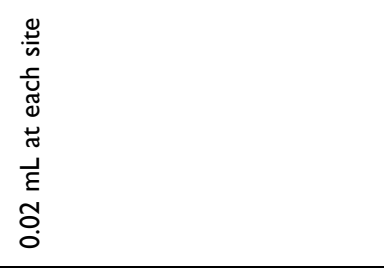 & 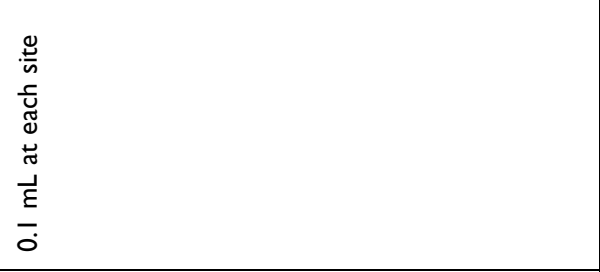 & \\
\hline 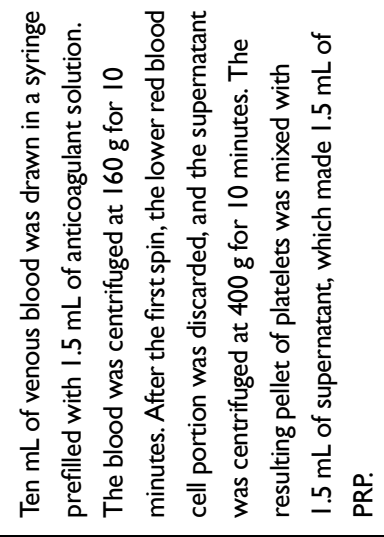 & 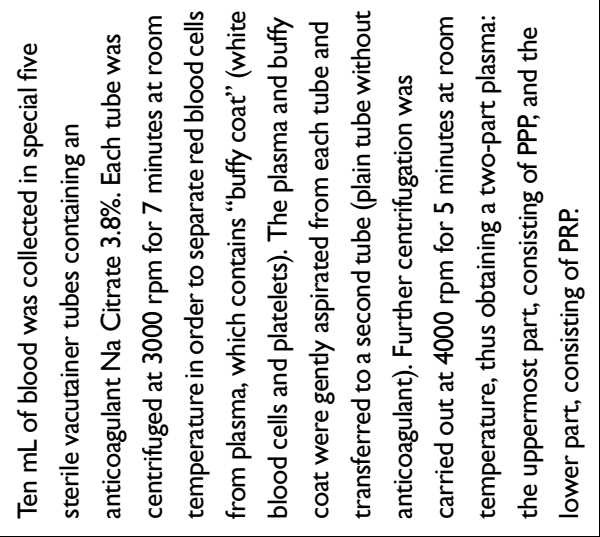 & 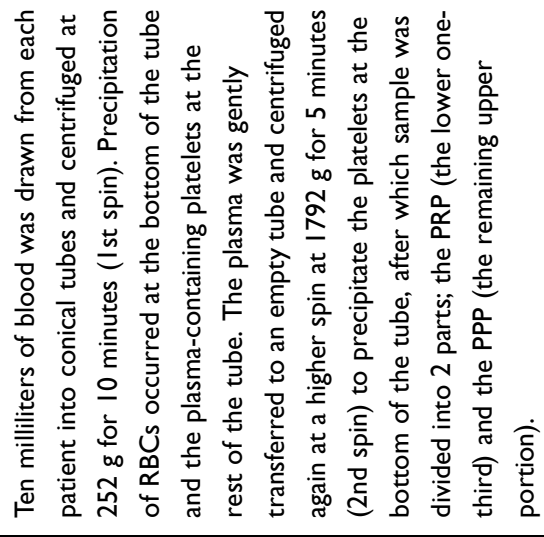 \\
\hline 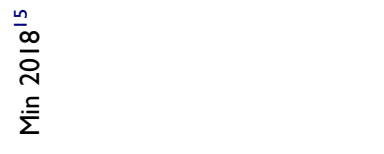 & 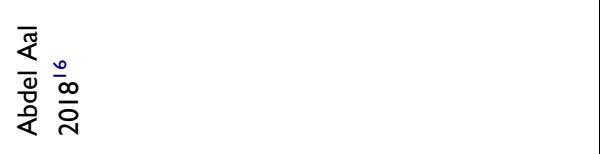 & 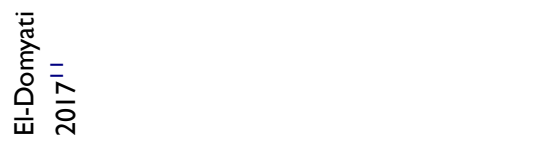 \\
\hline
\end{tabular}




\begin{tabular}{|c|c|c|c|c|}
\hline & 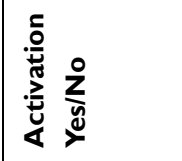 & & & $\check{\nu}^{\mathscr{y}}$ \\
\hline & 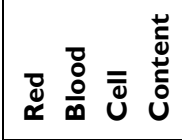 & & & . \\
\hline & 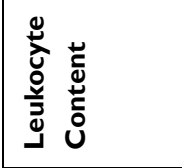 & & & . \\
\hline & 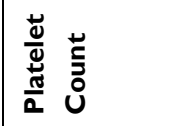 & & & 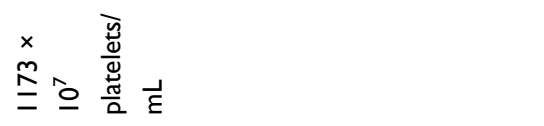 \\
\hline & 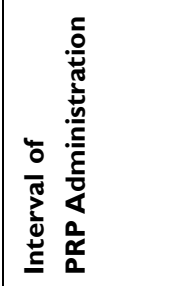 & 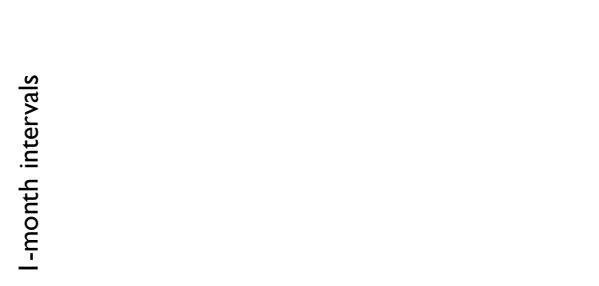 & 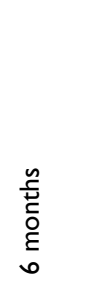 & 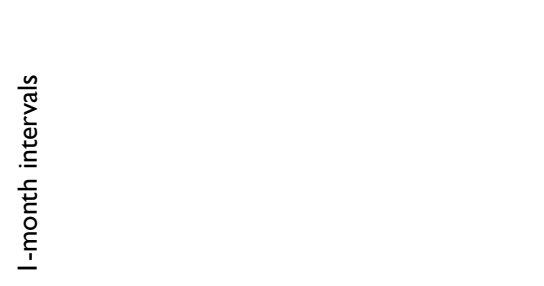 \\
\hline 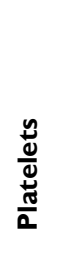 & 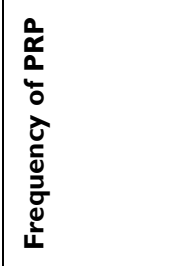 & $m$ & $N$ & $m$ \\
\hline & 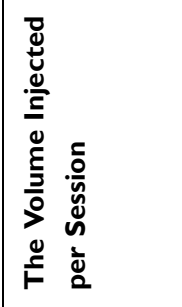 & & & $\underset{\sim}{\vec{\xi}}$ \\
\hline & 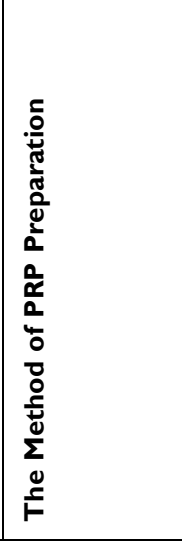 & 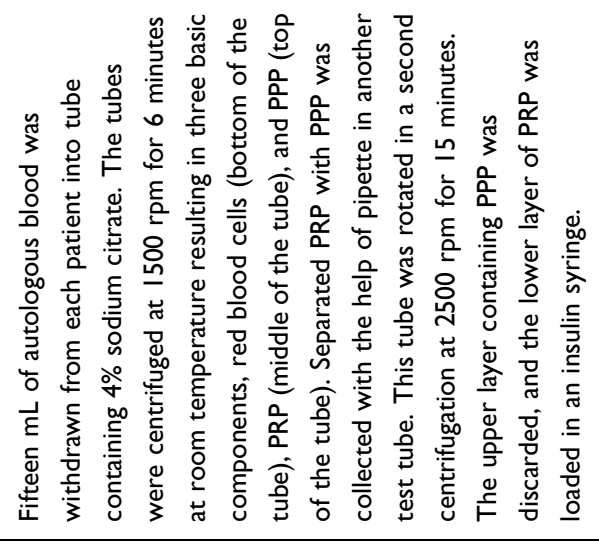 & 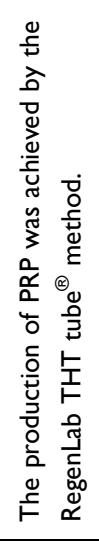 & 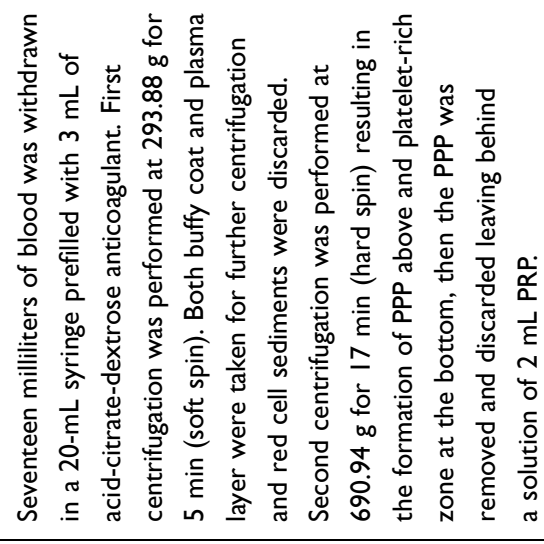 \\
\hline \multicolumn{2}{|c|}{ 竞 } & 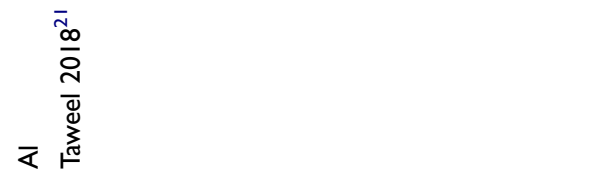 & 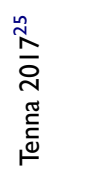 & $\begin{array}{l}\frac{1}{2} \\
\frac{0}{2} \\
\frac{1}{2}\end{array}$ \\
\hline
\end{tabular}




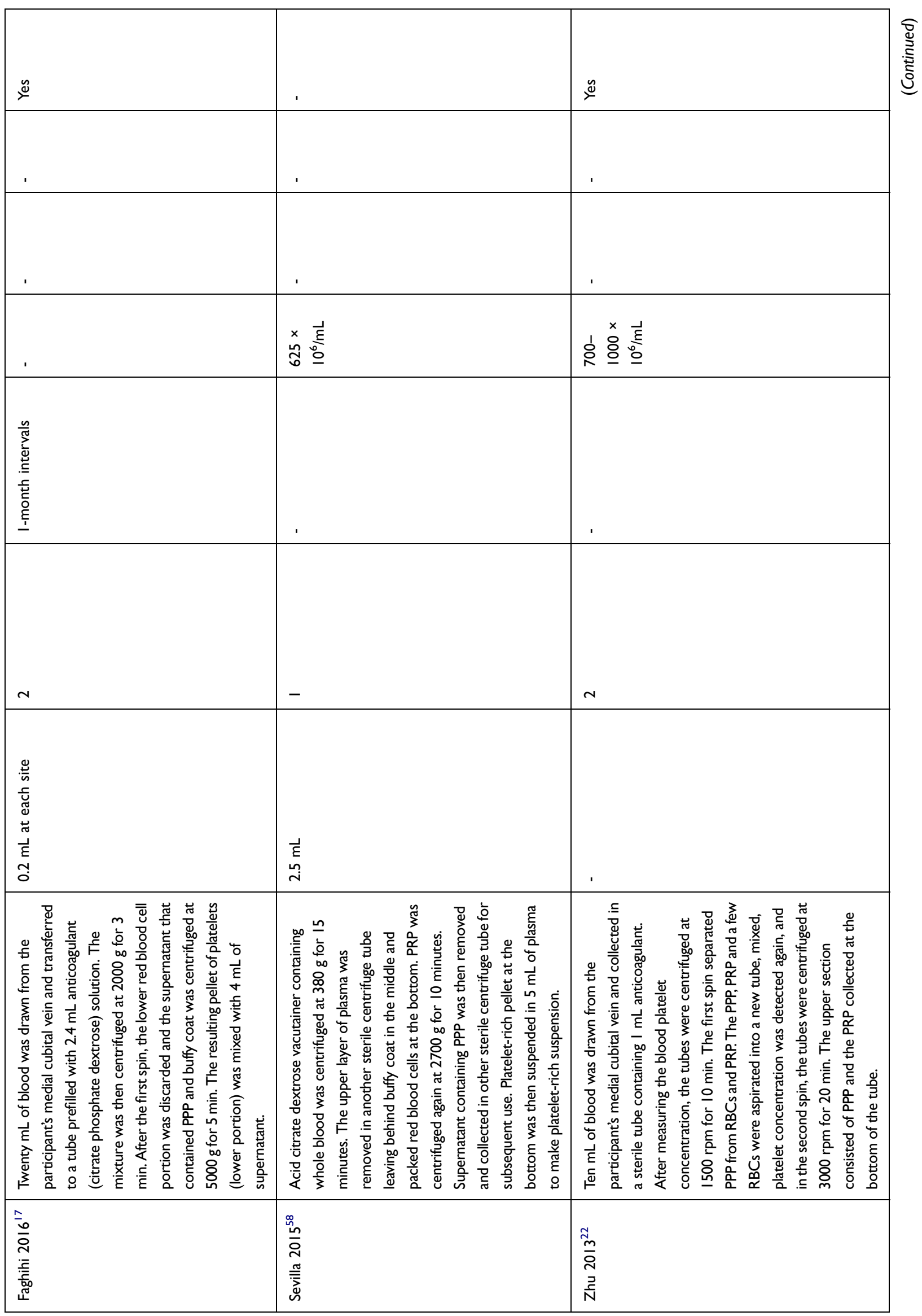




\begin{tabular}{|c|c|c|c|}
\hline & 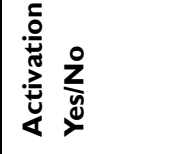 & . & $\stackrel{\stackrel{y}{\sim}}{ }$ \\
\hline & ¿্ঠ & . & ' \\
\hline & 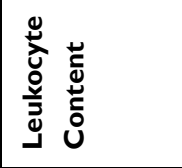 & & \\
\hline & 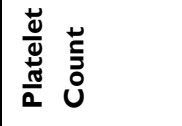 & ' & ' \\
\hline & 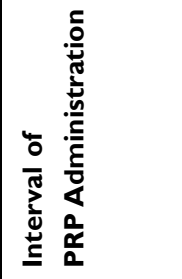 & 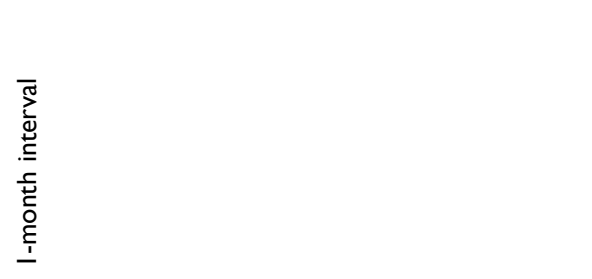 & 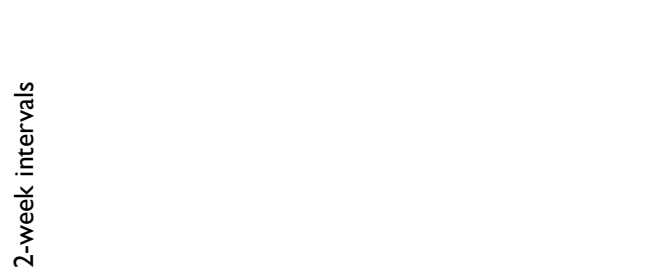 \\
\hline $\begin{array}{l}\frac{n}{0} \\
\frac{ \pm}{0} \\
\frac{\pi}{2}\end{array}$ & 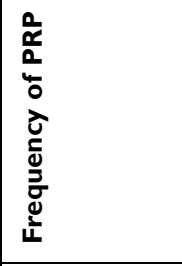 & $N$ & 0 \\
\hline & 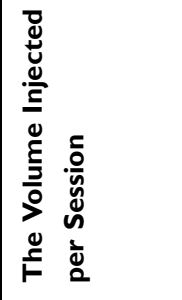 & 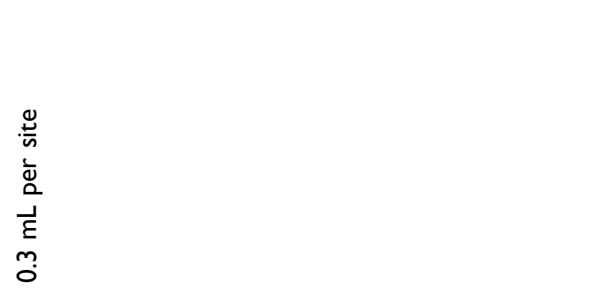 & \\
\hline & 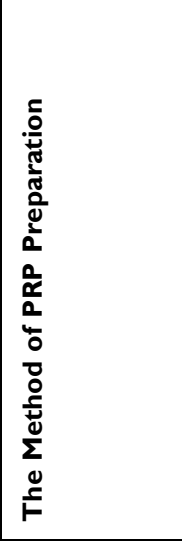 & 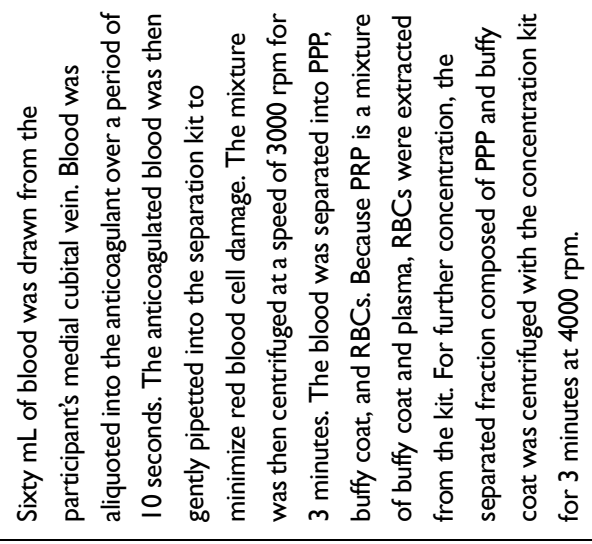 & 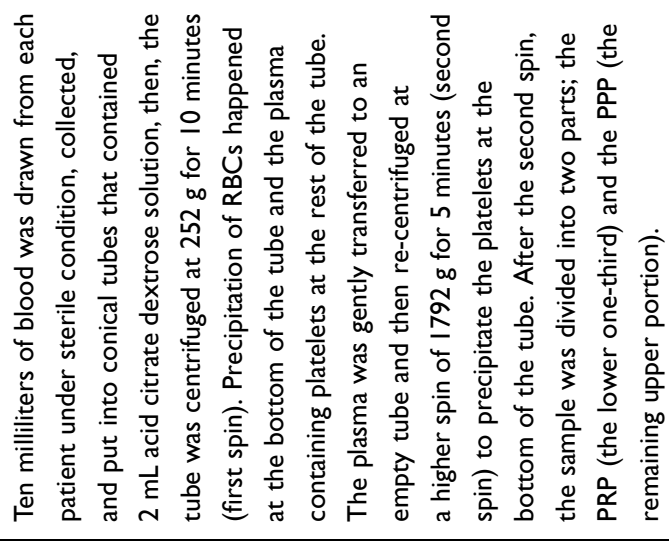 \\
\hline \multicolumn{2}{|c|}{ 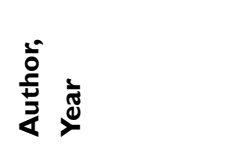 } & $\begin{array}{l}\stackrel{\infty}{\bar{D}} \\
\overline{\bar{N}} \\
\stackrel{\Xi}{\unlhd}\end{array}$ & 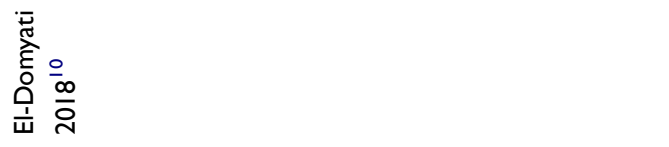 \\
\hline
\end{tabular}




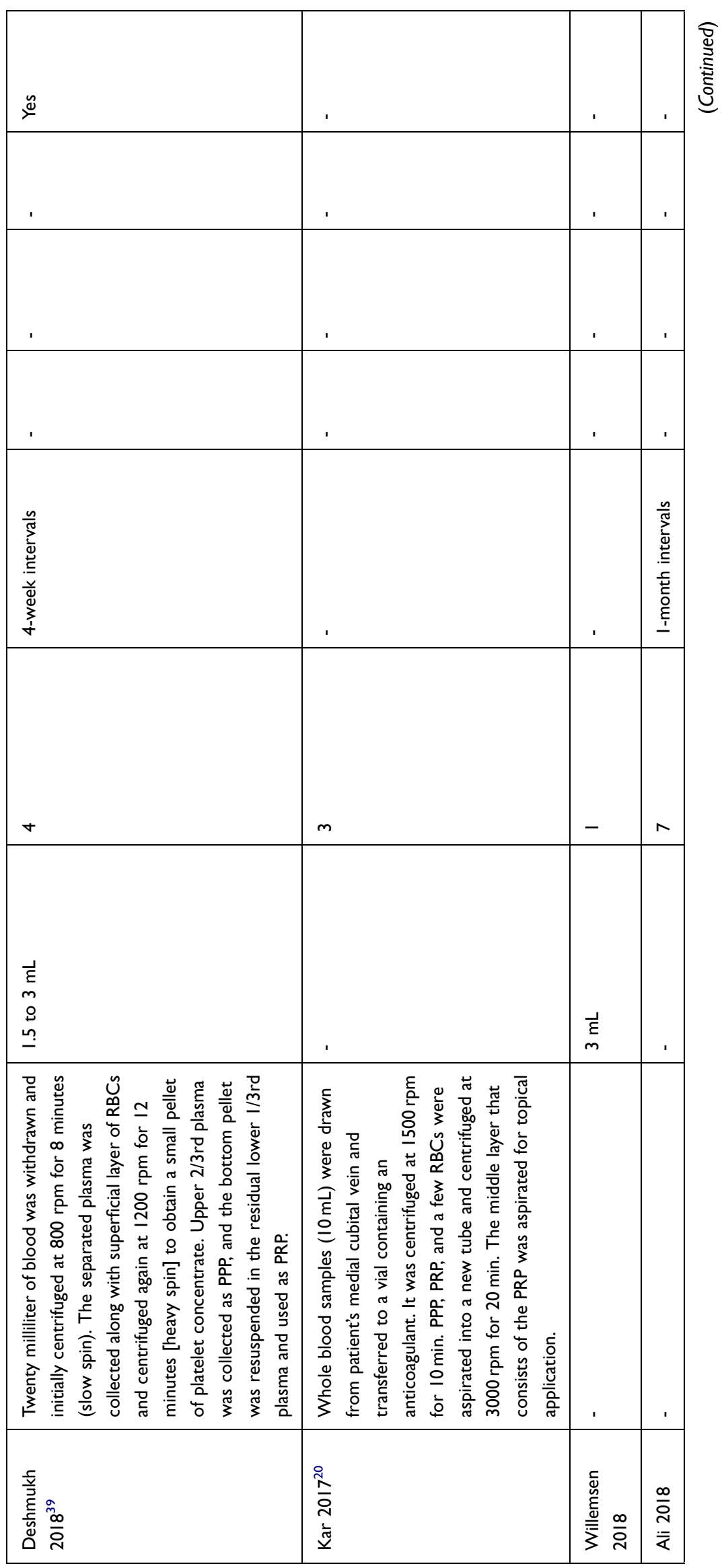




\begin{tabular}{|c|c|c|c|c|}
\hline & 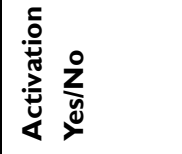 & $\stackrel{\mathscr{\nu}}{\check{\nu}}$ & ㅇ & $\stackrel{\mathscr{y}}{\succ}$ \\
\hline & ষ্ঠ & . & ' & . \\
\hline & 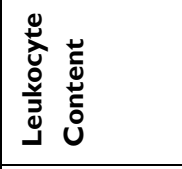 & & . & . \\
\hline & 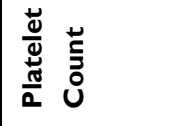 & , & ' & 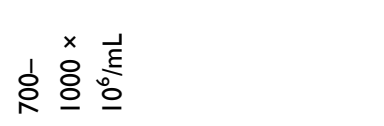 \\
\hline & 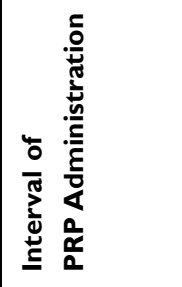 & ' & 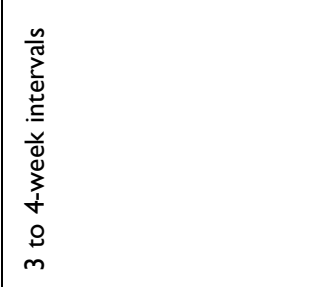 & 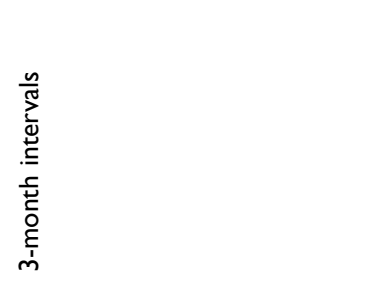 \\
\hline $\begin{array}{l}\frac{n}{0} \\
\frac{\pi}{0} \\
\frac{\pi}{2}\end{array}$ & 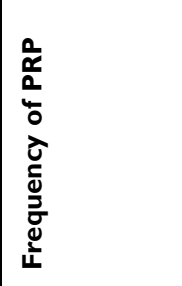 & 0 & 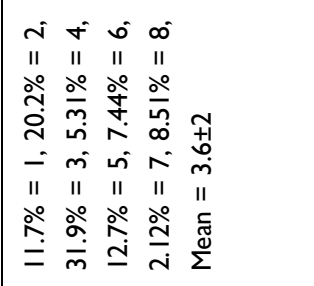 & $m$ \\
\hline & 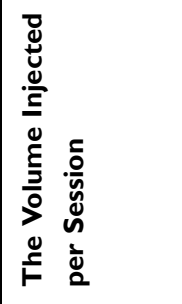 & 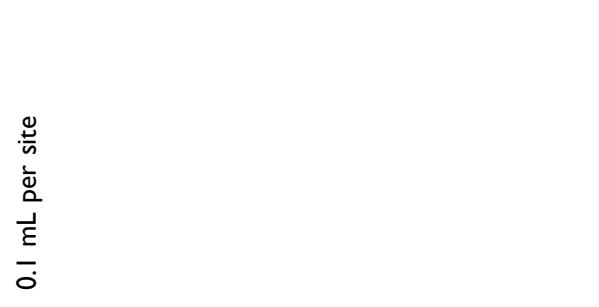 & & 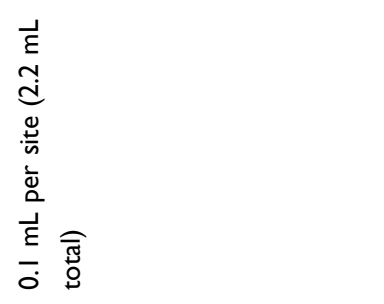 \\
\hline & 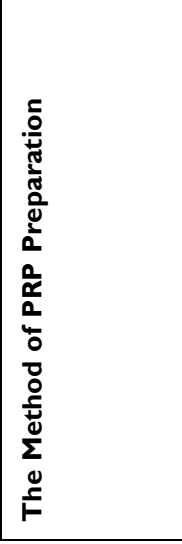 & 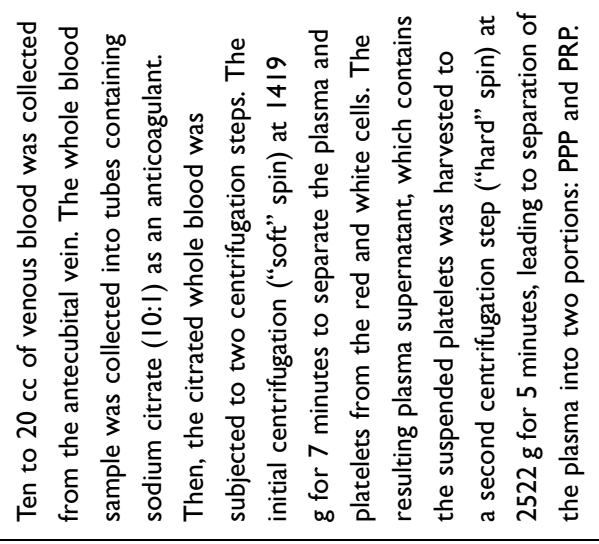 & 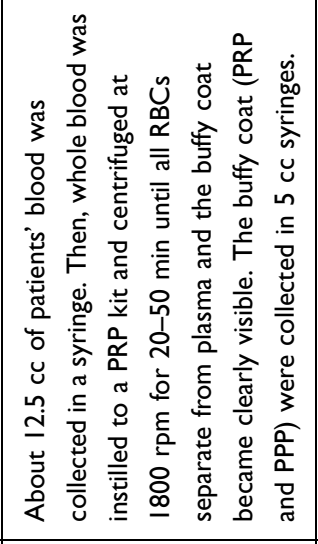 & 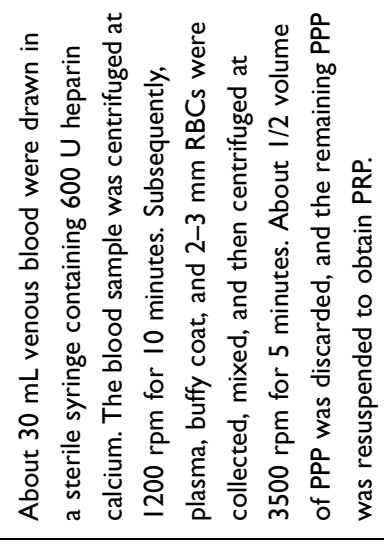 \\
\hline \multicolumn{2}{|c|}{ 琣 } & 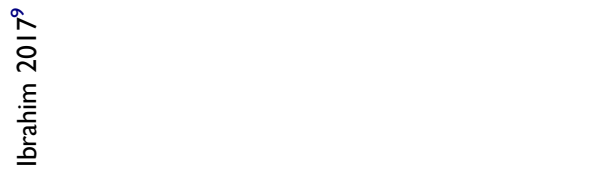 & $\begin{array}{l}\frac{n}{N} \\
\bar{N} \\
\overline{\tilde{n}} \\
\frac{\tilde{n}}{J}\end{array}$ & $\begin{array}{l}\frac{0}{N} \\
\overline{2} \\
\overline{3} \\
\overline{1}\end{array}$ \\
\hline
\end{tabular}




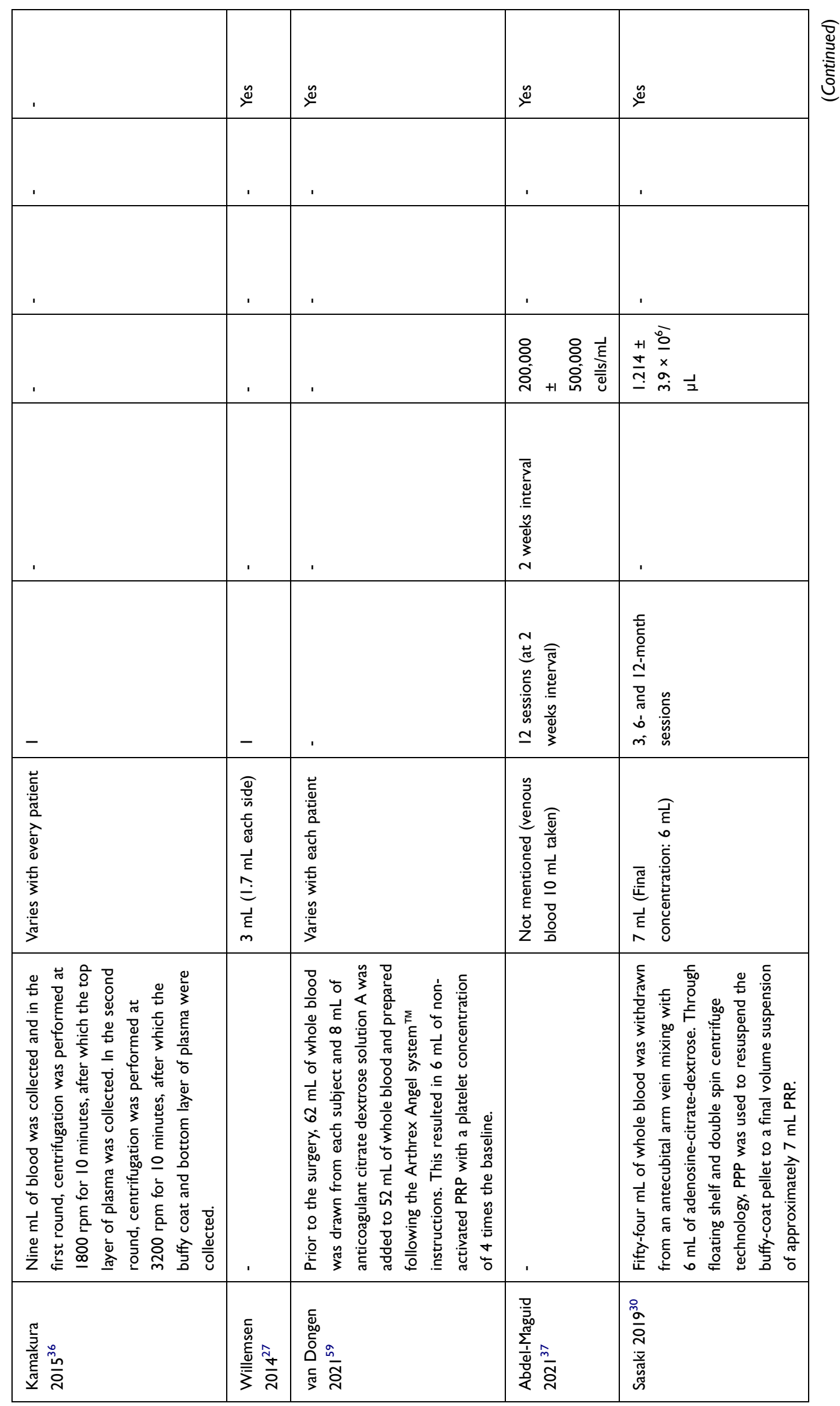




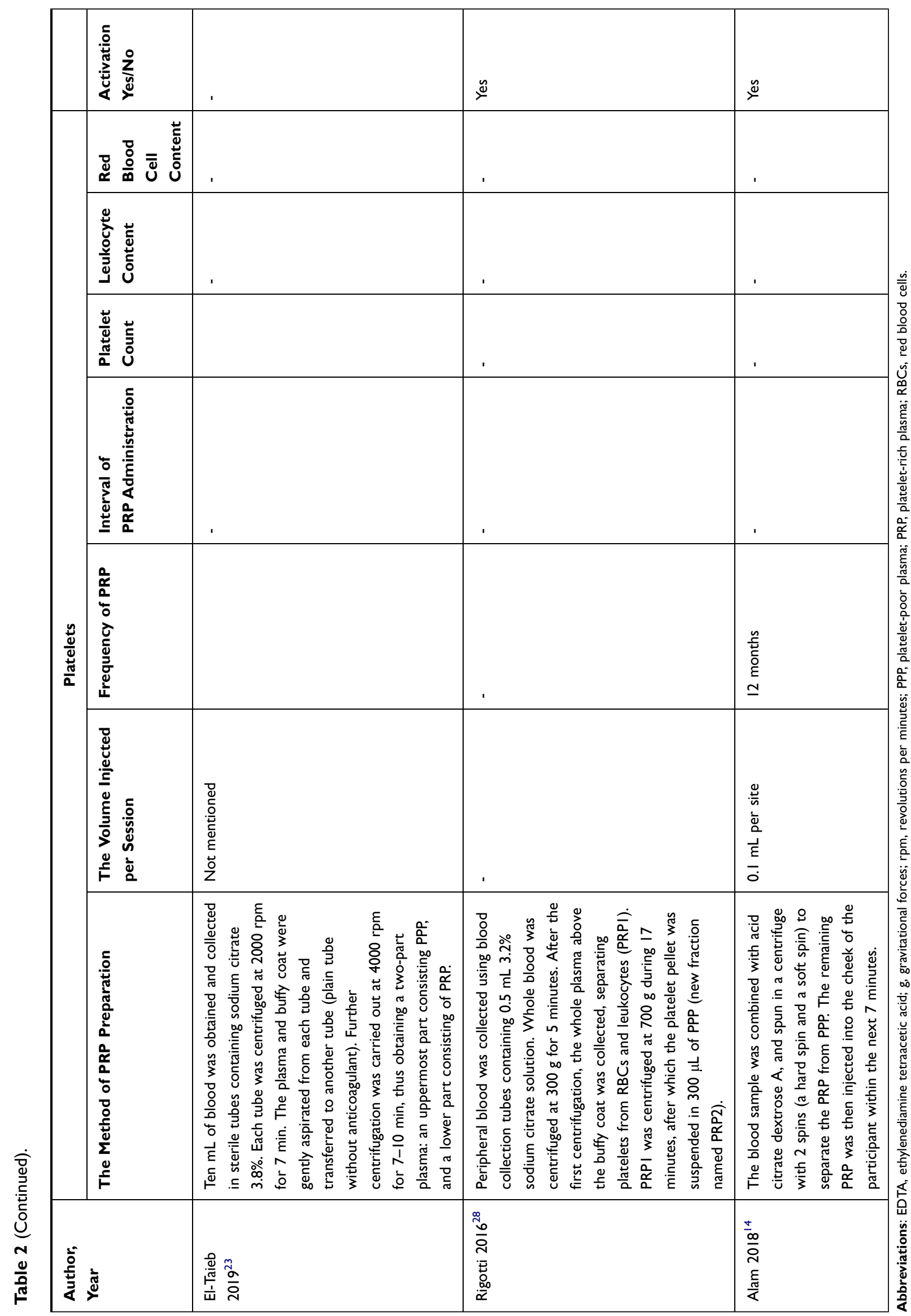


7 and 1 studies, respectively, which suggests a lack of a rational approach in determining the PRP administration volume. Because PRP is the first generation of platelet concentrate and other blood-derived platelet concentrates like the plateletrich fibrin is also used in clinical practice, it is essential to use a surrogate marker for determining the amount of growth factors in the PRP.

\section{Outcomes and End Point of Interest in PRP Treatment}

Apart from the administration dose of PRP, the lack of uniform assessment of efficacy is another important aspect of PRP treatment. The end points for determining efficacy were based on the desired treatment outcome. Among the included studies, the end points of efficacy ranged from the usage of the FACE Q questionnaire to an independent photographic assessment of wrinkles and acne (Table 3 ). The findings of combination therapy are presented in Table 4. A qualitative assessment of the included studies is provided in Table 5.

\section{Application of PRP in Facial Rejuvenation}

Among the studies that used PRP monotherapy, the mode of administration of PRP was an intradermal injection in all the studies except for one study in which it was used as a topical application. All studies reported significant improvement after PRP application although there is a lack of uniformity in assessment and reporting of the outcome measures. This makes it difficult to draw definitive conclusions based on the results reported in these studies. Results in 7 studies were assessed based on the photographs obtained at baseline and follow-up (Table 3).

PRP has several benefits in facial rejuvenation and due to its enormous benefits, it is being used in several conditions such as atrophic acne scars, pigmentation, facial wrinkles, facial folds, loss of elasticity, and loss of tissue volume. ${ }^{8}$

\section{PRP with Micro-Needling Applications}

PRP in conjunction with the micro-needling procedure was explored in 5 studies reporting significant effects in treating acne scars and facial aging. ${ }^{9-13}$ Ibrahim et al compared the efficacy and safety of micro-needling with PRP and microneedling alone in 35 patients with atrophic acne scars. Although significant improvement was observed after both the treatment modalities there was no significant difference between the 2 modalities as assessed by Goodman and Baron's global acne scarring system. However, regarding safety, PRP with micro-needling had significantly lesser erythema and edema than micro-needling alone, which could plausibly be attributed to the healing and tissue repair properties of PRP. ${ }^{13}$ A randomized study evaluated the effects of micro-needling and PRP both, alone and in combination, in 90 patients. There was a statistically significant improvement in the PRP and micro-needling group compared with PRP and microneedling alone. Moreover, the patient satisfaction was also statistically significant in the combination group compared with PRP and micro-needling groups alone. The authors suggest that the combination therapy is efficacious and safe in treating atrophic scars of different etiologies with minimal downtime and affordable cost. ${ }^{9}$ Asif et al assessed the combination efficacy of PRP with micro-needling in managing atrophic acne scars in 50 patients. Goodman's qualitative and quantitative scales showed significant improvement by microneedling alone and a combination of PRP and micro-needling. There was a significant difference between the 2 treatments modalities. Patient satisfaction scores were also significantly different between PRP and micro-needling and micro-needling alone. The authors propose a hypothesis that in combination therapy of micro-needling and PRP, the damage caused due to micro-needling is cured by the healing mechanism of the activated platelets, cytokines, and the growth factors from PRP. ${ }^{12}$ Another study compared a combination of PRP and micro-needling with micro-needling and trichloroacetic acid (TCA) peeling in 24 subjects with atrophic acne scars. Both the combinations showed significant improvement in acne scars, however, there was no significant difference by histometric evaluation of epidermal thickness. Although both the combination techniques were efficacious, micro-needling with TCA was preferred by the subjects over micro-needling with PRP for acne scars. ${ }^{11}$ A similar study of combination techniques for photoaging and facial wrinkles showed a significant increase in evaluation scores of PRP and micro-needling compared with micro-needling and TCA. Additionally, histological results also revealed improvement of dermal structures in microneedling and PRP combination compared with microneedling and TCA. ${ }^{10}$ In a recent randomized trial, Alam et al showed that PRP therapy improved the visual appearance in individuals with photoaged skin, the results showed that both fine and coarse texture improved significantly more with a single treatment of PRP than the individuals treated with normal saline. $^{14}$

\section{PRP with Laser Applications}

Laser treatment with PRP has been reported to produce superior results in treating acne scars and facial aging. Seven studies reported the efficacy of $\mathrm{CO}_{2}$ laser treatment in conjunction 


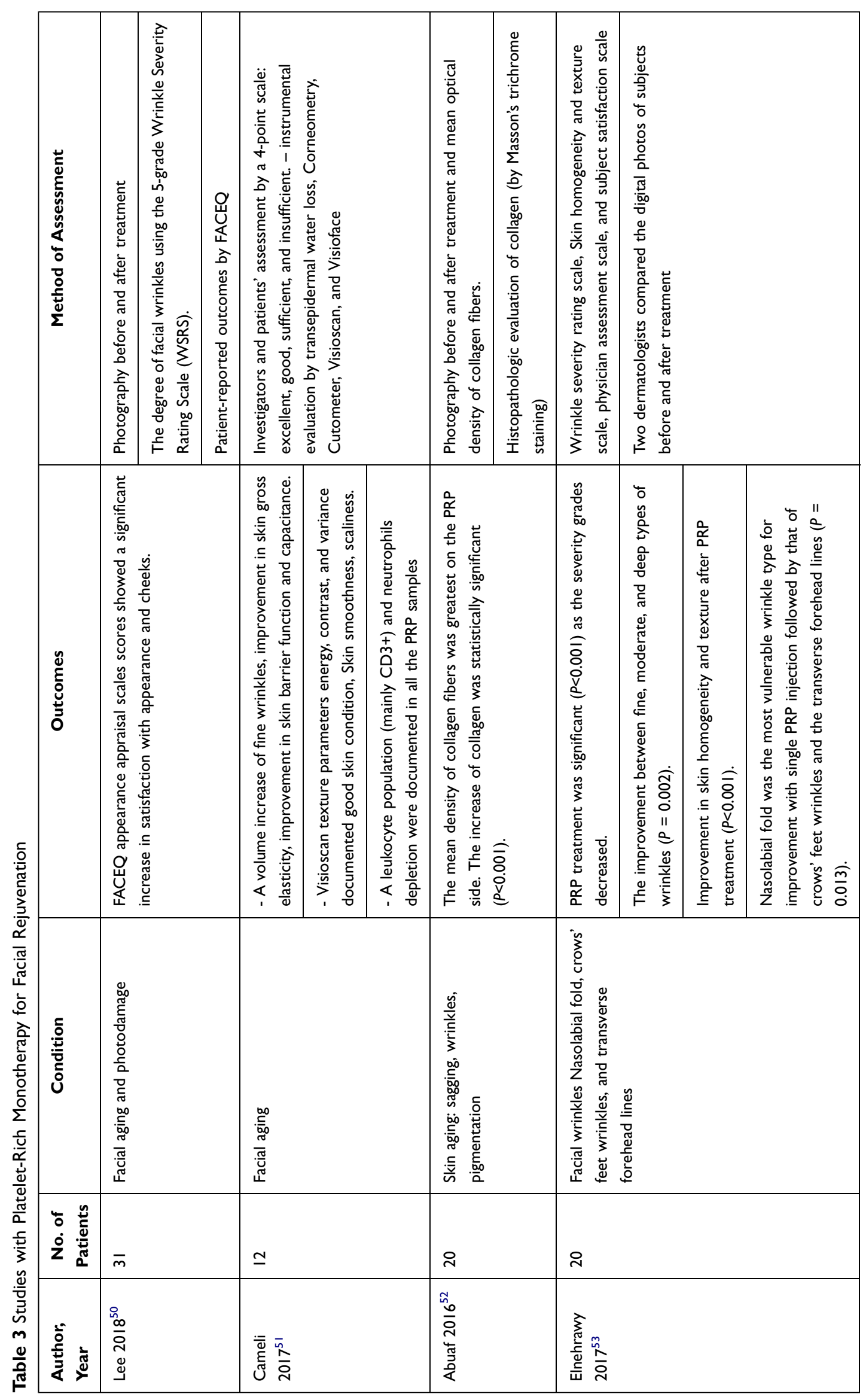




\begin{tabular}{|c|c|c|c|c|c|c|c|c|c|c|c|}
\hline \multicolumn{3}{|l|}{ 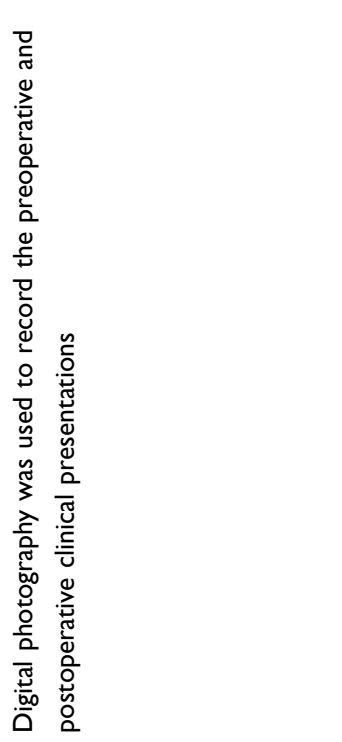 } & 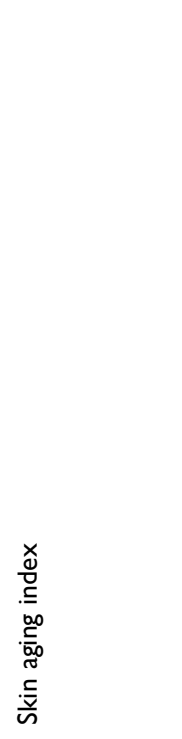 & 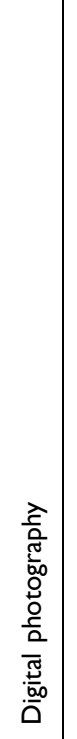 & 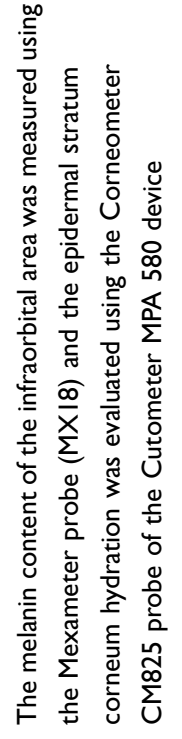 & 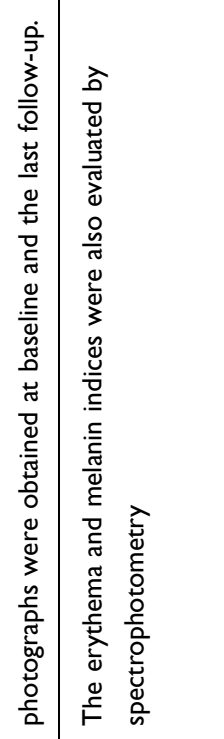 & 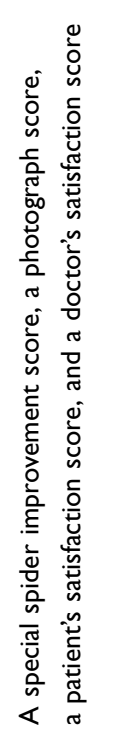 & \multicolumn{4}{|c|}{ 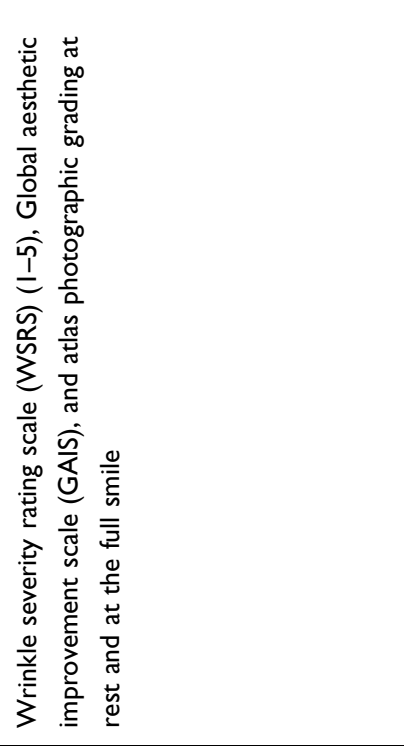 } \\
\hline 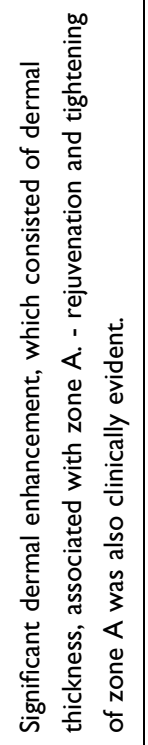 & 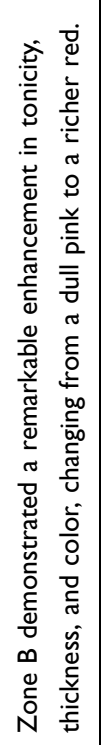 & 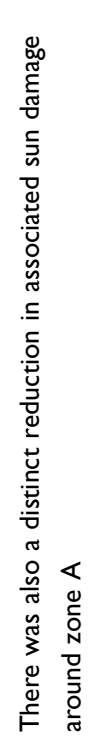 & 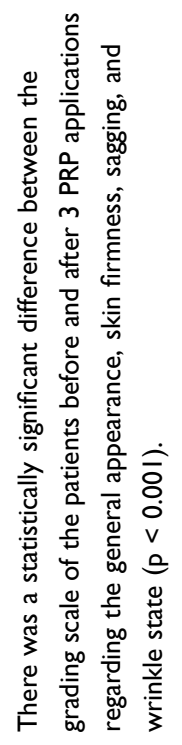 & 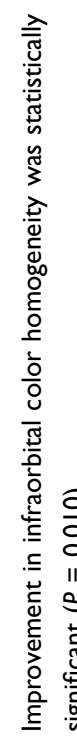 & & 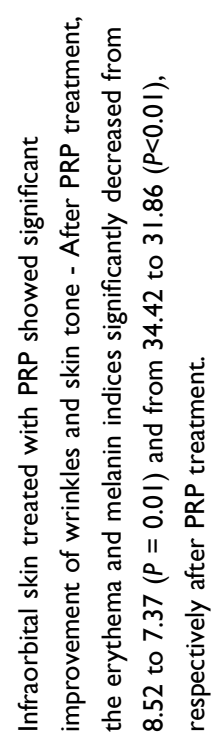 & 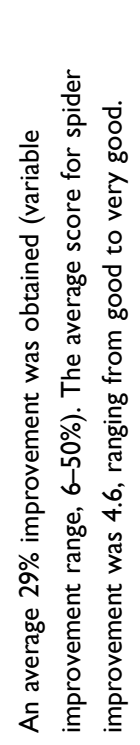 & 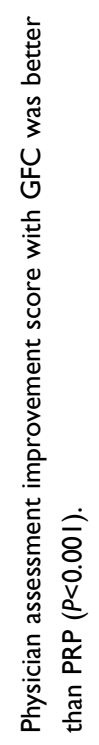 & 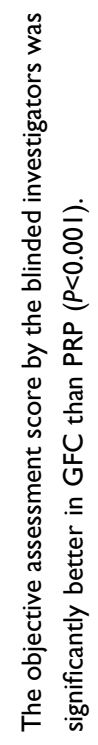 & 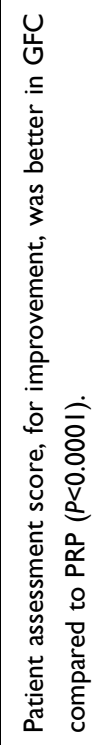 & 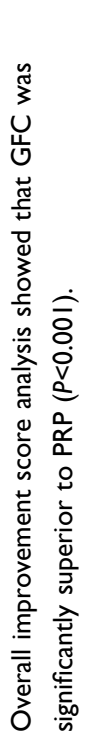 \\
\hline \multicolumn{3}{|c|}{ 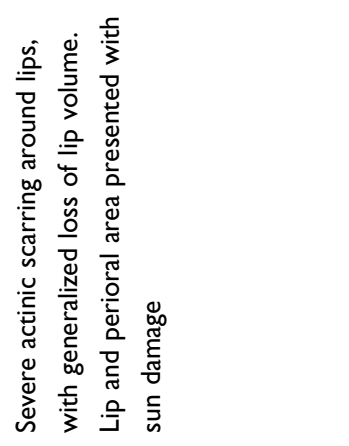 } & 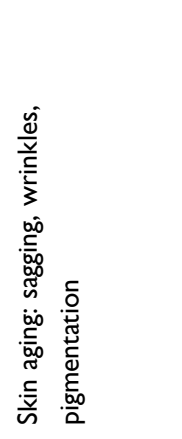 & 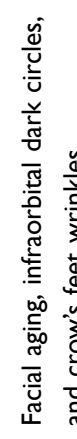 & & 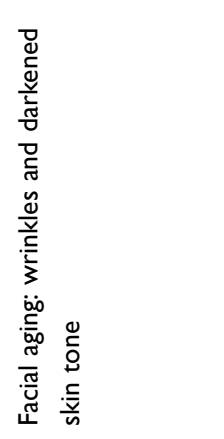 & 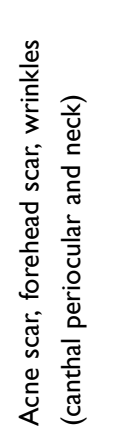 & \multicolumn{4}{|l|}{ 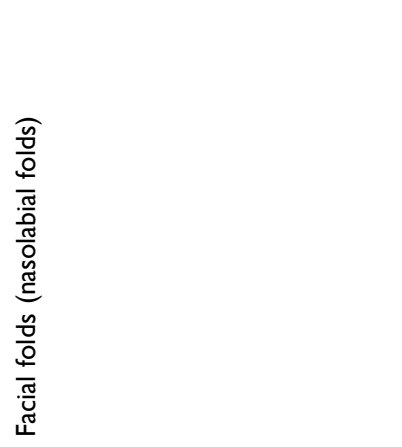 } \\
\hline \multicolumn{3}{|l|}{-} & 으 & 으 & & 요 & $\tilde{\sim}$ & \multicolumn{4}{|l|}{$\infty$} \\
\hline \multicolumn{3}{|l|}{ 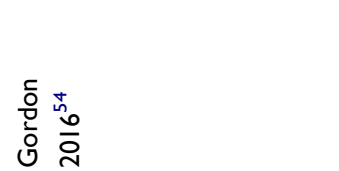 } & 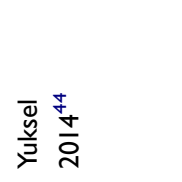 & 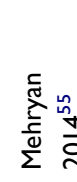 & & 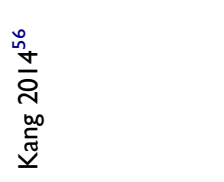 & 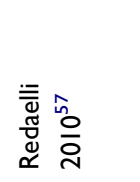 & \multicolumn{4}{|l|}{ 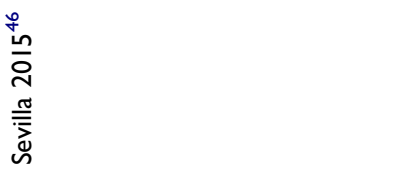 } \\
\hline
\end{tabular}




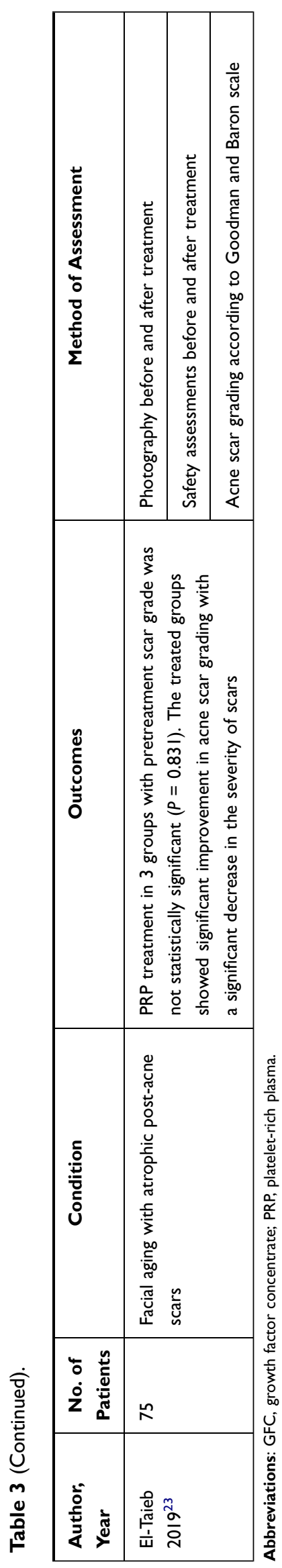

with PRP. Min et al evaluated the molecular mechanism of increased clinical efficacy of PRP combined with $\mathrm{CO} 2$ laser treatment in 25 subjects with acne scars. PRP in combination with $\mathrm{CO}_{2}$ laser treatment showed significant improvement as assessed by the investigator global assessment scale. Patient satisfaction scores were also significantly higher in PRP and $\mathrm{CO}_{2}$ laser treatment than $\mathrm{CO}_{2}$ treatment alone. Immunohistochemical results suggest that there was increased TGF $\beta 1$ and C-myc levels, and collagen 1 expression was significantly higher in combination treatment suggestive of the clinical efficacy of the combination therapy. ${ }^{15}$ Similar results were reported in other studies, ${ }^{16-19}$ Kar et al reported significant improvement on both sides of the face with combination treatment of fractional $\mathrm{CO}_{2}$ laser treatment along with PRP and treatment with $\mathrm{CO}_{2}$ for atrophic acne scars as assessed by Goodman and Barons quantitative global acne scar grading system, but there was no significant difference between right and left sides of the face. The authors conclude that in the PRP treatment there is a significant reduction in the downtime and the inflammation caused by laser treatment. ${ }^{20}$ AI Taweel et al investigated the efficacy of PRP combined with carboxytherapy compared with PRP with fractional $\mathrm{CO}_{2}$ laser treatment in 40 patients with atrophic acne scars. PRP combined with $\mathrm{CO}_{2}$ laser treatment significantly improved acne scars compared with PRP combined with carboxytherapy treatment. However, it was observed that carboxytherapy had fewer side effects than $\mathrm{CO}_{2}$ treatment and could be a beneficial treatment option for acne scars. ${ }^{21} \mathrm{Zhu}$ et al evaluated the efficacy and safety of erbium fractional laser treatment combined with PRP in treating acne scars. Combination therapy was given to 22 subjects and $90.9 \%$ of the patients showed an improvement of $>50 \%$, and $91 \%$ of the patients were satisfied with the treatment. The assessment was performed by comparing pre- and post-treatment photographs of the patients. The results suggest the efficacy and safety of the combination therapy in producing synergic benefits in the treatment of acne scars. ${ }^{22}$ Another recent clinical trial conducted by ElTaieb showed that combination treatment of PRP with the addition of erbium laser showed superior efficacy as compared with 12 sessions of single plasma-rich therapy over the same period. The clinical trial participants were assessed by acne scar grading, photography, and subjective evaluation. ${ }^{23}$

\section{PRP with Fat Grafting/Lipofilling Applications}

Fat grafting or lipofilling has gained importance as a surgical alternative due to its long-term results in treating 
Table 4 Studies with Platelet-Rich Combination Therapy for Facial Rejuvenation

\begin{tabular}{|c|c|c|c|c|c|}
\hline $\begin{array}{l}\text { Author, } \\
\text { Year }\end{array}$ & $\begin{array}{l}\text { No. of } \\
\text { Patients }\end{array}$ & Condition & Treatment & Outcomes & Methods of Assessment \\
\hline \multirow[t]{2}{*}{$\begin{array}{l}\text { lbrahim } \\
2018^{13}\end{array}$} & \multirow[t]{2}{*}{35} & \multirow[t]{2}{*}{$\begin{array}{l}\text { Atrophic post acne } \\
\text { scars }\end{array}$} & \multirow[t]{2}{*}{$\begin{array}{l}\text { PRP with micro- } \\
\text { needling }\end{array}$} & $\begin{array}{l}\text { Significant improvement in acne } \\
\text { scars and facial aging. }\end{array}$ & \multirow[t]{2}{*}{$\begin{array}{l}\text { Goodman and Baron's global acne } \\
\text { scarring system }\end{array}$} \\
\hline & & & & $\begin{array}{l}\text { PRP with micro-needling had } \\
\text { significantly lesser erythema and } \\
\text { edema compared to than micro- } \\
\text { needling alone }\end{array}$ & \\
\hline Min $2018^{15}$ & 25 & Acne scars & $\begin{array}{l}\text { PRP with } \\
\text { fractional } \mathrm{CO}_{2} \\
\text { laser treatment }\end{array}$ & $\begin{array}{l}\text { Significant improvement, Patient } \\
\text { satisfaction scores were also } \\
\text { significantly higher in } \mathrm{PRP} \text { and } \mathrm{CO}_{2} \\
\text { laser treatment than } \mathrm{CO}_{2} \text { treatment } \\
\text { alone. }\end{array}$ & $\begin{array}{l}\text { Investigator global assessment scale, } \\
\text { Patient satisfaction scores }\end{array}$ \\
\hline $\begin{array}{l}\text { Abdel Aal } \\
2018^{16}\end{array}$ & 30 & Acne scars & $\begin{array}{l}\text { PRP with } \\
\text { fractional } \mathrm{CO}_{2} \\
\text { laser treatment }\end{array}$ & $\begin{array}{l}\text { Combination of fractional } \mathrm{CO}_{2} \text { laser } \\
\text { resurfacing and intradermal PRP was } \\
\text { superior to } \mathrm{CO}_{2} \text { laser alone for acne } \\
\text { scar treatment }\end{array}$ & $\begin{array}{l}\text { Evaluation was carried out through } \\
\text { operating physicians, two blinded } \\
\text { physicians as well as through } \\
\text { patient's satisfaction. }\end{array}$ \\
\hline El- & & Domyati $2018^{11}$ & 24 & Atrophic acne scars & PRP with micro-needling \\
\hline $\begin{array}{l}\text { Al Taweel } \\
2018^{21}\end{array}$ & 40 & $\begin{array}{l}\text { Improvement of } \\
\text { dermal structures, } \\
\text { combination with } \\
\text { trichloroacetic acid } \\
\text { more effective } \\
\text { than PRP } \\
\text { Atrophic acne } \\
\text { scars }\end{array}$ & $\begin{array}{l}\text { PRP combined } \\
\text { with } \\
\text { carboxytherapy } \\
\text { and PRP with } \\
\mathrm{CO}_{2} \text { laser } \\
\text { treatment }\end{array}$ & $\begin{array}{l}\text { PRP combined with } \mathrm{CO}_{2} \text { laser } \\
\text { treatment significantly improved } \\
\text { acne scars compared with PRP } \\
\text { combined with carboxytherapy } \\
\text { treatment. }\end{array}$ & $\begin{array}{l}\text { Photographs and patient satisfaction } \\
\text { score }\end{array}$ \\
\hline $\begin{array}{l}\text { Tenna } \\
2017^{25}\end{array}$ & 30 & $\begin{array}{l}\text { Atrophic acne } \\
\text { scars }\end{array}$ & $\begin{array}{l}\text { Fat grafts with } \\
\text { PRP }\end{array}$ & $\begin{array}{l}\text { Improved scars by increasing skin } \\
\text { and subcutaneous tissue thickness }\end{array}$ & $\begin{array}{l}\text { FACE-Q postoperative module was } \\
\text { administered to analyze each } \\
\text { patient's satisfaction }\end{array}$ \\
\hline Asif $2016^{12}$ & 50 & Atrophic scars & $\begin{array}{l}\text { PRP with micro- } \\
\text { needling }\end{array}$ & $\begin{array}{l}\text { Significant improvement in atrophic } \\
\text { acne scars. Patient satisfaction } \\
\text { scores were also significantly } \\
\text { different between PRP and micro- } \\
\text { needling }\end{array}$ & $\begin{array}{l}\text { Goodman's qualitative and } \\
\text { quantitative scales }\end{array}$ \\
\hline $\begin{array}{l}\text { Faghihi } \\
2016^{17}\end{array}$ & 16 & $\begin{array}{l}\text { Atrophic acne } \\
\text { scars: }\end{array}$ & $\begin{array}{l}\text { PRP with } \\
\text { fractional } \mathrm{CO}_{2} \\
\text { laser treatment }\end{array}$ & $\begin{array}{l}\text { Clinical improvement of acne scars } \\
\text { was higher on the platelet-rich } \\
\text { plasma-fractional } \mathrm{CO}_{2} \text { laser treated } \\
\text { side but the difference was not } \\
\text { statistically significant. }\end{array}$ & $\begin{array}{l}\text { Patient satisfaction and the objective } \\
\text { evaluation of serial photographs }\end{array}$ \\
\hline Zhu $2013^{22}$ & 22 & Acne or acne scar & $\begin{array}{l}\text { PRP with } \\
\text { fractional } \mathrm{CO}_{2} \\
\text { laser treatment }\end{array}$ & $\begin{array}{l}\text { Improvement of }>50 \% \text {, and } 91 \% \text { of } \\
\text { the patients were satisfied with the } \\
\text { treatment. }\end{array}$ & $\begin{array}{l}\text { Comparing pre- and post-treatment } \\
\text { photographs of the patients }\end{array}$ \\
\hline
\end{tabular}

(Continued) 
Table 4 (Continued).

\begin{tabular}{|c|c|c|c|c|c|}
\hline $\begin{array}{l}\text { Author, } \\
\text { Year }\end{array}$ & $\begin{array}{l}\text { No. of } \\
\text { Patients }\end{array}$ & Condition & Treatment & Outcomes & Methods of Assessment \\
\hline Lee $2011^{18}$ & 14 & Acne scars & $\begin{array}{l}\text { PRP with } \\
\text { fractional } \mathrm{CO}_{2} \\
\text { laser treatment }\end{array}$ & $\begin{array}{l}\text { Enhanced recovery of laser-damaged } \\
\text { skin and synergistically improved the } \\
\text { clinical appearance of acne scarring. }\end{array}$ & $\begin{array}{l}\text { Dermatologists evaluated clinical } \\
\text { improvement using a quartile } \\
\text { grading scale }\end{array}$ \\
\hline El- & & Domyati $2018^{10}$ & 24 & $\begin{array}{l}\text { Facial wrinkles and other signs of } \\
\text { photoaging }\end{array}$ & PRP with micro-needling \\
\hline $\begin{array}{l}\text { Significant } \\
\text { clinical } \\
\text { Deshmukh } \\
2018^{39}\end{array}$ & 40 & $\begin{array}{l}\text { improvement after } \\
\text { treatment } \\
\text { Atrophic acne } \\
\text { scars }\end{array}$ & $\begin{array}{l}\text { Photography and } \\
\text { punch biopsies } \\
\text { PRP with } \\
\text { subcutaneous } \\
\text { incision-less } \\
\text { surgery } \\
\text { (subcision) }\end{array}$ & $\begin{array}{l}\text { Significant improvement was } \\
\text { observed in PRP plus subcision } \\
\text { compared with subcision alone. }\end{array}$ & $\begin{array}{l}\text { Goodman and Baron's qualitative } \\
\text { acne scar grading system }\end{array}$ \\
\hline Kar $2017^{20}$ & 30 & $\begin{array}{l}\text { Atrophic acne } \\
\text { scars }\end{array}$ & $\begin{array}{l}\text { PRP with } \\
\text { fractional } \mathrm{CO}_{2} \\
\text { laser treatment }\end{array}$ & $\begin{array}{l}\text { Significant improvement on both } \\
\text { sides of the face. }\end{array}$ & $\begin{array}{l}\text { Goodman and Barons quantitative } \\
\text { global acne scar grading system }\end{array}$ \\
\hline $\begin{array}{l}\text { Willemsen } \\
2018^{26}\end{array}$ & 32 & $\begin{array}{l}\text { Loss of skin } \\
\text { elasticity and tissue } \\
\text { volume }\end{array}$ & $\begin{array}{l}\text { PRP with } \\
\text { lipofilling }\end{array}$ & $\begin{array}{l}\text { No improvement in the outcome } \\
\text { about skin elasticity, graft volume } \\
\text { maintenance, and patient } \\
\text { satisfaction, however, the recovery } \\
\text { time was significantly reduced due to } \\
\text { addition of PRP }\end{array}$ & $\begin{array}{l}\text { Changes in skin elasticity, volumetric } \\
\text { changes of the nasolabial fold, } \\
\text { recovery time, and patient } \\
\text { satisfaction }\end{array}$ \\
\hline Ali $2018^{32}$ & 63 & Facial aging & $\begin{array}{l}\text { PRP with thread- } \\
\text { lifting }\end{array}$ & $\begin{array}{l}\text { Highly augmented results are } \\
\text { observed when combined with PRP }\end{array}$ & Patient satisfaction \\
\hline $\begin{array}{l}\text { Ibrahim } \\
2017^{9}\end{array}$ & 90 & $\begin{array}{l}\text { Atrophic post-acne } \\
\text { scars, atrophic } \\
\text { post-traumatic } \\
\text { scars, post } \\
\text { chickenpox scars }\end{array}$ & $\begin{array}{l}\text { PRP with micro- } \\
\text { needling }\end{array}$ & $\begin{array}{l}\text { Significant improvement in the } \\
\text { appearance of atrophic scars }\end{array}$ & Clinical evaluation scale score \\
\hline $\begin{array}{l}\text { Ulusal } \\
2017^{35}\end{array}$ & 94 & Facial aging & $\begin{array}{l}\text { PRP with } \\
\text { hyaluronic acid }\end{array}$ & $\begin{array}{l}\text { Significant improvement was } \\
\text { observed regarding the general } \\
\text { appearance }\end{array}$ & $\begin{array}{l}\text { 5-grade wrinkle severity rating scale } \\
\text { and by patient satisfaction scores. }\end{array}$ \\
\hline Hui $2017^{19}$ & 13 & Facial aging & $\begin{array}{l}\text { PRP with } \\
\text { fractional } \mathrm{CO}_{2} \\
\text { laser treatment }\end{array}$ & $\begin{array}{l}\text { Subjective scores of facial wrinkles, } \\
\text { skin texture, and skin elasticity were } \\
\text { higher }\end{array}$ & $\begin{array}{l}\text { Satisfaction scores, dermatologists' } \\
\text { double-blind evaluation and the } \\
\text { VISIA skin analysis system }\end{array}$ \\
\hline $\begin{array}{l}\text { Kamakura } \\
2015^{36}\end{array}$ & 2005 & $\begin{array}{l}\text { Wrinkles and } \\
\text { depression in the } \\
\text { skin }\end{array}$ & $\begin{array}{l}\text { PRP with growth } \\
\text { factor }\end{array}$ & $\begin{array}{l}\text { Level of patient satisfaction was } \\
97.3 \% \text { and the level of investigator } \\
\text { satisfaction was } 98.4 \% \text {. }\end{array}$ & $\begin{array}{l}\text { Global Aesthetic Improvement } \\
\text { Scale, Wrinkle Severity Rating Scale }\end{array}$ \\
\hline $\begin{array}{l}\text { Willemsen } \\
2014^{27}\end{array}$ & 82 & $\begin{array}{l}\text { Loss of tissue } \\
\text { volume, significant } \\
\text { ptosis, and the } \\
\text { subsequent } \\
\text { descent of tissues }\end{array}$ & $\begin{array}{l}\text { PRP with fat } \\
\text { grafting }\end{array}$ & $\begin{array}{l}\text { Significant drop in the number of } \\
\text { days needed to recover. }\end{array}$ & Questionnaire based evaluation \\
\hline
\end{tabular}

(Continued) 
Table 4 (Continued).

\begin{tabular}{|c|c|c|c|c|c|}
\hline $\begin{array}{l}\text { Author, } \\
\text { Year }\end{array}$ & $\begin{array}{l}\text { No. of } \\
\text { Patients }\end{array}$ & Condition & Treatment & Outcomes & Methods of Assessment \\
\hline $\begin{array}{l}\text { van } \\
\text { Dongen } \\
2021^{59}\end{array}$ & 28 & Facial aging & $\begin{array}{l}\text { PRP } \\
\text { supplemented } \\
\text { lipofilling with } \\
\text { stromal vascular } \\
\text { fraction }\end{array}$ & $\begin{array}{l}\text { In comparison to PRP-supplemented } \\
\text { lipofilling, PRP-supplemented } \\
\text { lipofilling combined with stromal } \\
\text { vascular fraction does not improve } \\
\text { facial skin quality or patient } \\
\text { satisfaction. }\end{array}$ & $\begin{array}{l}\text { Changes in skin elasticity and } \\
\text { transepidermal water loss, changes } \\
\text { in skin-aging-related features, ie, } \\
\text { superficial spots, wrinkles, skin } \\
\text { texture, pores, vascularity, and } \\
\text { pigmentation, as well as patient } \\
\text { satisfaction (FACE-Q), recovery, and } \\
\text { number of complications }\end{array}$ \\
\hline Abdel- & & Maguid $2021^{37}$ & 33 & Atrophic acne scars. & PRP with fractional $\mathrm{CO}_{2}$ laser \\
\hline $\begin{array}{l}\text { Better and } \\
\text { faster } \\
\text { Sasaki } \\
2019^{30}\end{array}$ & 10 & $\begin{array}{l}\text { improvement, } \\
\text { dermal collagen } \\
\text { and procollagen } \\
\text { type I was } \\
\text { increased after } \\
\text { PRP therapy } \\
\text { Facial aging }\end{array}$ & $\begin{array}{l}\text { Clinical } \\
\text { assessment and } \\
\text { Skin biopsies } \\
\text { PRP with fat } \\
\text { grafting }\end{array}$ & $\begin{array}{l}\text { Improvement in the average percent } \\
\text { change in mean volume assessments } \\
\text { at the fat/PRP sites from baseline } \\
\text { values }\end{array}$ & $\begin{array}{l}\text { 3D Vectra Analysis, VISIA, and } \\
\text { Cortex facial skin analyses }\end{array}$ \\
\hline $\begin{array}{l}\text { El-Taieb } \\
2019^{23}\end{array}$ & 75 & $\begin{array}{l}\text { Atrophic acne } \\
\text { scars }\end{array}$ & $\begin{array}{l}\text { PRP with erbium } \\
\text { laser }\end{array}$ & $\begin{array}{l}\text { Improvement with combined } \\
\text { treatment was better than that with } \\
\text { erbium-YAG laser or platelet-rich } \\
\text { plasma alone }\end{array}$ & $\begin{array}{l}\text { Acne scar grading, photography, and } \\
\text { subjective evaluation. }\end{array}$ \\
\hline $\begin{array}{l}\text { Rigotti } \\
2016^{28}\end{array}$ & 13 & Facial aging & $\begin{array}{l}\text { PRP with fat } \\
\text { grafting }\end{array}$ & $\begin{array}{l}\text { Presence of more pronounced } \\
\text { inflammatory infiltrates and } \\
\text { a greater vascular reactivity, } \\
\text { increasing in vascular permeability } \\
\text { and a certain reactivity of the } \\
\text { nervous component. }\end{array}$ & $\begin{array}{l}\text { Clinical observation, optical and } \\
\text { electron microscopy }\end{array}$ \\
\hline $\begin{array}{l}\text { Alam } \\
2018^{14}\end{array}$ & 27 & Facial aging & $\begin{array}{l}\text { PRP with micro- } \\
\text { needling }\end{array}$ & $\begin{array}{l}\text { Improved the visual appearance in } \\
\text { individuals with photoaged skin, fine } \\
\text { and coarse texture improved } \\
\text { significantly. }\end{array}$ & $\begin{array}{l}\text { Photoaging scores, self-assessment } \\
\text { scores of improvements on } \\
\text { a } 5 \text {-point scale }\end{array}$ \\
\hline
\end{tabular}

Abbreviations: $\mathrm{CO}_{2}$, carbon-dioxide; PRP, platelet-rich plasma.

acne scars. ${ }^{24}$ A study comparing the efficacy of nano fat and PRP with or without fractional $\mathrm{CO}_{2}$ laser in treating atrophic scars revealed that both the combination treatments were efficacious in improving scars by increasing skin and subcutaneous tissue thickness with no significant difference between the 2 types of combinations. ${ }^{25}$ A double-blind, placebo-controlled, randomized trial on the efficacy of PRP with lipofilling in patients with loss of skin elasticity and tissue volume revealed no improvement in the outcome about skin elasticity, graft volume maintenance, and patient satisfaction, however, the recovery time was significantly reduced due to addition of $\mathrm{PRP}^{26} \mathrm{~A}$ retrospective study evaluated the effects of PRP on the recovery time and aesthetic outcome in treating loss of tissue volume, significant ptosis, and the subsequent descent of tissues. The patients were divided into 4 groups consisting of fat grafts only, fat grafting and PRP, minimal access cranial suspension (MACS) lift and fat grafting, and MACS-lift, fat grafting, and PRP. It was observed that there was a significant drop in the recovery days after the addition of PRP to lipofilling and additionally the aesthetic outcome was also better in fat grafting and PRP group. The results of the 
Table 5 Evidence Grading of the Studies Included in the Literature Review

\begin{tabular}{|c|c|c|c|c|}
\hline \multirow[t]{2}{*}{ Author } & \multirow[t]{2}{*}{ No. of Patients } & \multirow[t]{2}{*}{ Therapy } & \multicolumn{2}{|c|}{ Quality Assessment } \\
\hline & & & Newcastle-Ottawa Scale (NOS) & JADAD Scale \\
\hline Lee $2018^{50}$ & 31 & PRP monotherapy & 4 & - \\
\hline Cameli $2017^{51}$ & 12 & PRP monotherapy & 4 & - \\
\hline Abuaf $2016^{52}$ & 20 & PRP monotherapy & 8 & - \\
\hline Elnehrawy $2017^{53}$ & 20 & PRP monotherapy & 3 & - \\
\hline Gordon $2016^{54}$ & 1 & PRP monotherapy & - & - \\
\hline Yuksel $2014^{44}$ & 10 & PRP monotherapy & 4 & - \\
\hline Mehryan $2014^{55}$ & 10 & PRP monotherapy & 4 & - \\
\hline Kang $2014^{56}$ & 20 & PRP monotherapy & - & 2 \\
\hline Redaelli $2010^{57}$ & 23 & PRP monotherapy & 4 & - \\
\hline Sevilla $2015^{58}$ & 80 & PRP monotherapy & 5 & - \\
\hline Ibrahim $2018^{13}$ & 35 & Combination therapy & 6 & - \\
\hline Min $2018^{15}$ & 25 & Combination therapy & 4 & - \\
\hline Abdel Aal $2018^{16}$ & 30 & Combination therapy & 6 & - \\
\hline El-Domyati $2018^{11}$ & 24 & Combination therapy & 6 & - \\
\hline Al Taweel $2018^{21}$ & 40 & Combination therapy & 5 & - \\
\hline Tenna $2017^{25}$ & 30 & Combination therapy & 5 & - \\
\hline Asif $2016^{12}$ & 50 & Combination therapy & 5 & \\
\hline Faghihi $2016^{17}$ & 16 & Combination therapy & 6 & \\
\hline Zhu $2013^{22}$ & 22 & Combination therapy & 5 & \\
\hline Lee $201 I^{18}$ & 14 & Combination therapy & 5 & \\
\hline El-Domyati $2018^{10}$ & 24 & Combination therapy & 6 & - \\
\hline Deshmukh $2018^{39}$ & 40 & Combination therapy & 6 & - \\
\hline $\operatorname{Kar} 2017^{20}$ & 30 & Combination therapy & 4 & - \\
\hline Willemsen $2018^{26}$ & 32 & Combination therapy & - & 5 \\
\hline Ali $2018^{32}$ & 63 & Combination therapy & 4 & - \\
\hline Ibrahim $2017^{9}$ & 90 & Combination therapy & 5 & - \\
\hline Ulusal $2017^{35}$ & 94 & Combination therapy & 5 & - \\
\hline Hui $2017^{19}$ & 13 & Combination therapy & 6 & - \\
\hline Kamakura $2015^{36}$ & 2005 & Combination therapy & 4 & - \\
\hline Willemsen $2014^{27}$ & 82 & Combination therapy & 5 & - \\
\hline van Dongen $2021^{59}$ & 28 & Combination therapy & - & 2 \\
\hline Abdel-Maguid $2021^{37}$ & 33 & Combination therapy & - & 2 \\
\hline Sasaki $2019^{30}$ & 10 & Combination therapy & - & 1 \\
\hline El-Taieb $2019^{23}$ & 75 & Combination therapy & - & 2 \\
\hline Rigotti $2016^{28}$ & 13 & Combination therapy & - & 2 \\
\hline Alam $2018^{14}$ & 27 & Combination therapy & - & 2 \\
\hline
\end{tabular}

Note: OS was used for assessing the quality of the non-randomized study; the JADAD scale is used for assessing randomized trials.

assessment were based on pre- and post-photographs evaluated by plastic surgeons. ${ }^{27} \mathrm{~A}$ study by Rigotti et al ${ }^{28}$ demonstrated that treatment with expanded adiposederived stem cells or stromal vascular fraction (SVF) enriched fat modified the pattern of the subcutaneous dermis and thus producing a skin rejuvenation effect. SVF represents a rich reservoir of regenerative precursor cells. ${ }^{29}$ However, the PRP therapy did not have any significant advantages in producing any skin rejuvenation effect over the adipose-derived stem cells or enriched fat.
However, another study conducted by Van Dongen showed that PRP supplemented lipofilling did not improve the facial skin quality or patient satisfaction in a population consisting of healthy individuals. Concerning the safety profile, the investigators concluded that PRP supplemented lipofilling supplemented with a SVF could be considered a safe procedure. Additionally, in a study conducted by Sasaki et al, fat grafting techniques combined with PRP therapy showed improvement in the average percent change in mean volume assessments at the fat/PRP sites from baseline values, as 
profiled by 3D Vectra Analysis, demonstrated a higher, but statistically nonsignificant value over 1 year than the percent value changes at the fat/normal saline sites in the opposing face or hand. ${ }^{30}$ The large variation in the outcomes of fat grafting when PRP was added might be attributed to the presence or absence of inflammatory leukocytes or reactive oxygen species in erythrocytes. ${ }^{31}$

\section{PRP with Thread-Lifting Applications}

Ali et al evaluated the 2-year outcome of thread lifting with absorbable barbed polydioxanone (PDO) threads with or without PRP in the treatment of facial aging. Thread lifting had significant effects on skin lifting and patient satisfaction. Significant results were also seen with thread lifting combined with PRP. ${ }^{32}$

\section{PRP with Hyaluronic Acid Applications}

Research studies have shown that by combining hyaluronic acid (HA) and PRP, the synergic effect of the treatment would be associated with the enhanced function of dermal fibrosis, thus providing better outcomes in facial rejuvenation. ${ }^{33,34}$ Ulusal et al studied the effect of HA with PRP in facial aging. Significant improvement was observed regarding the general appearance as graded by the physicians on the 5 -grade wrinkle severity rating scale and by patient satisfaction scores. However, there was no significant difference in the aesthetic improvement scores provided by patients and physicians after treatment. ${ }^{35}$

\section{PRP with Growth Factor Applications}

A combination of growth factors with PRP has shown to be an effective treatment in facial rejuvenation. Kamakura et al studied the efficacy and safety of PRP with growth factors for treating wrinkles and depressed areas of the skin of 2005 patients. Patient and investigator satisfaction was $97.3 \%$ and $98.4 \%$, respectively, as assessed by the global aesthetic improvement scale. Ratings by wrinkle severity rating scale also showed improvement in the grade with PRP and growth factor combination suggesting that this is an effective and safe treatment of wrinkles with minimal complications. ${ }^{36} \mathrm{~A}$ recent prospective clinical trial conducted by Abdel-Maguid et al in a head-to-head trial to determine the efficacy of stem cell-conditioned medium after fractional $\mathrm{CO}_{2}$ laser (FCL) compared with combined FCL and PRP, the results showed better and faster improvement with FCL plus PRP than FCL. In 33 patients dermal collagen and procollagen type 1 was increased after PRP therapy in 3 sessions. ${ }^{37}$

\section{PRP with Subcision Applications}

Subcutaneous incision-less surgery (subcision) is also a widely used technique for treating acne scars. ${ }^{38}$ Deshmukh et al studied the effect of subcision adjunct to PRP in treating atrophic acne scars in 44 patients. Significant improvement was observed in PRP plus subcision compared with subcision alone. Goodman and Baron's qualitative acne scar grading system revealed statistically significant improvement with PRP plus subcision compared with subcision alone $(32.08 \%$ vs $8.33 \%, P=$ 0.04). Patients' objective scores also increased significantly in combination therapy suggestive of the synergic effect of the treatment. However, post-inflammatory pigmentation was reported as a side effect of the treatment. ${ }^{39}$

\section{Implementation of the Standard Classification System for PRP}

The optimal PRP platelet concentration is unclear; however, the current methods ${ }^{40,41}$ by which PRP is prepared reported $>1 \times 10^{6}$ platelets/ $\mu \mathrm{L}$ having $300 \%$ to $700 \%$ enrichment. $^{42}$ In most cosmetic procedures for dermatological conditions such as acne scar, facial rejuvenation, and graft survival in hair transplantation, higher concentrations of platelet-derived growth factors are appropriate to use for obtaining better results. ${ }^{43,44}$ Even though there is enormous evidence of the benefits of PRP in facial rejuvenation, conflicting results are reported in the literature. Moreover, there is no standard reporting system for PRP to deduce and replicate the results of the published literature. PRP preparation includes various steps such as platelet concentration, white blood cells, red blood cells, and use of activators. Details of these along with the volume delivered are not reported in all the published literature evaluating the efficacy and safety of PRP. Although there are a few recommendations and classifications proposed for the adoption of reporting important characteristics of the PRP preparation in the scientific literature, ${ }^{45-47}$ as evident from our systematic review, none of these are implemented at large. Additionally, following a standard method to measure the outcomes is also an important factor for clinicians and researchers for interpretation and reproduction of the published literature to obtain the optimal results of PRP as the need for its use continues to grow in facial rejuvenation. Similar interpretations were made by Hausauer and Humphrey in a two-part systematic review and expert analysis where they performed an indepth analysis of PRP in hair restoration, soft-tissue 
remodeling, resurfacing, and rejuvenation. They found a wide variation in study methodologies with different protocols and differences in outcomes measured in different studies for indication of PRP in facial rejuvenation. $^{48,49}$ Hence, in the future, it is of utmost importance to standardize the methods of PRP preparation and optimize treatment methods in order to further improve its usefulness.

There are a few limitations in this systematic review, firstly most of the studies included were of observational design with very few being RCTs. The reporting of the PRP preparation was improper and a few of the studies did not include a standard outcome measurement tool and hence statistical synthesis of the outcomes could not be performed.

\section{Conclusion}

PRP has beneficial effects on facial rejuvenation either alone or in combination with other treatment modalities such as laser treatment, fat grafting, subcision, growth factors, and thread lifting. This systematic literature review reveals the high potential of PRP in generating growth factors combined with platelets that render healing effect is essentially a minimally invasive technique for the treatment of skin acne scars and aging. However, due to the lack of uniformity in reporting PRP preparation and employing standard valid assessment methods to report outcomes, there is paucity in proving the therapeutic benefits of PRP using meta-analysis with the available data. Large scale, randomized, control studies employing standard PRP preparation protocols and standard reporting systems are warranted to further validate the use of PRP in facial rejuvenation.

\section{Ethics Approval and Informed Consent}

Since this is a systematic literature review, the studies included had obtained informed consent as well as approval from their respective ethics committee.

\section{Consent for Publication}

All the authors have given their consent for the publication of this study.

\section{Acknowledgments}

Medical writing assistance was provided by Dr. Kaushik Subramanian and Dr. Amit, Indegene Pvt Ltd, Bengaluru, India.

\section{Funding}

This study did not receive any specific grant from any funding agency or non-profit organization.

\section{Disclosure}

The authors have no conflicts of interest in this work.

\section{References}

1. Goel S. Facial rejuvenation: an evolving world. Off Sci J Delhi Ophthalmol Soc. 2016;27(2):132-135. doi:10.7869/djo.226

2. American SOciety of plastic surgeons. 2018 plastic surgery statistics. Available from: https://www.plasticsurgery.org/documents/News/ Statistics/2018/plastic-surgery-statistics-full-report-2018.pdf. Accessed September 14, 2021.

3. Lei X, Xu P, Cheng B. Problems and solutions for platelet-rich plasma in facial rejuvenation: a systematic review. Aesth Plast Surg. 2019;43(2):457-469. doi:10.1007/s00266-018-1256-1

4. Motosko CC, Khouri KS, Poudrier G, Sinno S, Hazen A. Evaluating platelet-rich therapy for facial aesthetics and alopecia: a critical review of the literature. Plast Reconstr Surg. 2018;141 (5):1115-1123. doi:10.1097/PRS.0000000000004279

5. El-Husseiny RM, Saleh HM, Moustafa AA, Salem SA. Comparison between single- versus double-spin prepared platelet-rich plasma injection in treatment of female pattern hair loss: clinical effect and relation to vascular endothelial growth factor. Arch Dermatol Res. 2021;313(7):557-566. doi:10.1007/s00403-020-02134-6

6. Sclafani AP. Platelet-rich fibrin matrix for improvement of deep nasolabial folds. J Cosmet Dermatol. 2010;9(1):66-71. doi:10.1111/ j.1473-2165.2010.00486.x

7. Reksodiputro MH, Harahap AR, Setiawan L, Yosia M. A modified preparation method of ideal platelet-rich fibrin matrix from whole blood. Front Med (Lausanne). 2021;8:724488. doi:10.3389/ fmed.2021.724488

8. Molloy T, Wang Y, Murrell G. The roles of growth factors in tendon and ligament healing. Sports Med. 2003;33(5):381-394. doi:10.2165/ 00007256-200333050-00004

9. Ibrahim ZA, El-Ashmawy AA, Shora OA. Therapeutic effect of microneedling and autologous platelet-rich plasma in the treatment of atrophic scars: a randomized study. J Cosmet Dermatol. 2017;16 (3):388-399. doi:10.1111/jocd.12356

10. El-Domyati M, Abdel-Wahab H, Hossam A. Combining microneedling with other minimally invasive procedures for facial rejuvenation: a split-face comparative study. Int J Dermatol. 2018;57:1324-1334. doi:10.1111/ijd.14172

11. El-Domyati M, Abdel-Wahab H, Hossam A. Microneedling combined with platelet-rich plasma or trichloroacetic acid peeling for management of acne scarring: a split-face clinical and histologic comparison. J Cosmet Dermatol. 2018;17(1):73-83. doi:10.1111/ jocd. 12459

12. Asif M, Kanodia S, Singh K. Combined autologous platelet-rich plasma with microneedling verses microneedling with distilled water in the treatment of atrophic acne scars: a concurrent split-face study. J Cosmet Dermatol. 2016;15(4):434-443. doi:10.1111/ jocd. 12207

13. Ibrahim MK, Ibrahim SM, Salem AM. Skin microneedling plus platelet-rich plasma versus skin microneedling alone in the treatment of atrophic post acne scars: a split face comparative study. J Dermatol Treat. 2018;29(3):281-286. doi:10.1080/09546634.2017.1365111

14. Alam M, Hughart R, Champlain A, et al. Effect of platelet-rich plasma injection for rejuvenation of photoaged facial skin: a randomized clinical trial. JAMA Dermatol. 2018;154(12):1447. doi:10.1001/jamadermatol.2018.3977 
15. Min S, Yoon JY, Park SY, Moon J, Kwon HH, Suh DH. Combination of platelet rich plasma in fractional carbon dioxide laser treatment increased clinical efficacy of for acne scar by enhancement of collagen production and modulation of laser-induced inflammation: PRP WITH FRACTIONAL CO 2 LASER FOR ACNE SCAR. Lasers Surg Med. 2018;50(4):302-310. doi:10.1002/1sm.22776

16. Abdel Aal AM, Ibrahim IM, Sami NA, Abdel Kareem IM. Evaluation of autologous platelet-rich plasma plus ablative carbon dioxide fractional laser in the treatment of acne scars. J Cosmet Laser Ther. 2018;20(2):106-113. doi:10.1080/14764172.2017.1368667

17. Faghihi G, Keyvan S, Asilian A, Nouraei S, Behfar S, Nilforoushzadeh M. Efficacy of autologous platelet-rich plasma combined with fractional ablative carbon dioxide resurfacing laser in treatment of facial atrophic acne scars: a split-face randomized clinical trial. Indian J Dermatol Venereol Leprol. 2016;82(2):162. doi:10.4103/0378-6323.174378

18. Lee JW, Kim BJ, Kim MN, Mun SK. The efficacy of autologous platelet rich plasma combined with ablative carbon dioxide fractional resurfacing for acne scars: a simultaneous split-face trial. Dermatol Surg. 2011;37(7):931-938. doi:10.1111/j.1524-4725.2011.01999.x

19. Hui Q, Chang P, Guo B, Zhang Y, Tao K. The clinical efficacy of autologous platelet-rich plasma combined with ultra-pulsed fractional CO2 laser therapy for facial rejuvenation. Rejuvenation Res. 2017;20 (1):25-31. doi:10.1089/rej.2016.1823

20. Kar BR, Raj C. Fractional CO2 laser vs fractional CO2 with topical platelet-rich plasma in the treatment of acne scars: a split-face comparison trial. J Cutan Aesthet Surg. 2017;10(3):136-144. doi:10.4103/JCAS.JCAS_99_17

21. Al Taweel A, Al Refae A, Hamed AM, Kamal AM. Comparative study of the efficacy of platelet-rich plasma combined with carboxytherapy vs its use with fractional carbon dioxide laser in atrophic acne scars. J Cosmet Dermatol. 2018. doi:10.1111/jocd.12561

22. Zhu J-T, Xuan M, Zhang Y-N, et al. The efficacy of autologous platelet-rich plasma combined with erbium fractional laser therapy for facial acne scars or acne. Mol Med Rep. 2013;8(1):233-237. doi:10.3892/mmr.2013.1455

23. El-Taieb MA, Ibrahim HM, Hegazy EM, Ibrahim AK, Gamal AM, Nada EA. Fractional erbium-YAG laser and platelet-rich plasma as single or combined treatment for atrophic acne scars: a randomized clinical trial. Dermatol Ther (Heidelb). 2019;9(4):707-717. doi:10.1007/s13555-019-00318-1

24. Barret JP, Sarobe N, Grande N, Vila D, Palacin JM. Maximizing results for lipofilling in facial reconstruction. Clin Plast Surg. 2009;36(3):487-492. doi:10.1016/j.cps.2009.02.005

25. Tenna S, Cogliandro A, Barone $\mathrm{M}$, et al. Comparative study using autologous fat grafts plus platelet-rich plasma with or without fractional $\mathrm{CO} 2$ laser resurfacing in treatment of acne scars: analysis of outcomes and satisfaction with FACE-Q. Aesthetic Plast Surg. 2017;41(3):661-666. doi:10.1007/s00266-017-0777-3

26. Willemsen JCN, Van Dongen J, Spiekman M, et al. The addition of platelet-rich plasma to facial lipofilling: a double-blind, placebo-controlled, randomized trial. Plast Reconstr Surg. 2018;141 (2):331-343. doi:10.1097/PRS.0000000000004081

27. Willemsen JCN, van der Lei B, Vermeulen KM, Stevens HP. The effects of platelet-rich plasma on recovery time and aesthetic outcome in facial rejuvenation: preliminary retrospective observations. Aesthetic Plast Surg. 2014;38(5):1057-1063. doi:10.1007/s00266014-0361-z

28. Rigotti G, Charles-de-sá L, Gontijo-de-amorim NF, et al. Expanded stem cells, stromal-vascular fraction, and platelet-rich plasma enriched fat: comparing results of different facial rejuvenation approaches in a clinical trial. Aesthet Surg J. 2016;36(3):261-270. doi:10.1093/asj/sjv231

29. Gir P, Oni G, Brown SA, Mojallal A, Rohrich RJ. Human adipose stem cells: current clinical applications. Plast Reconstr Surg. 2012;129(6):1277-1290. doi:10.1097/PRS.0b013e31824ecae6
30. Sasaki GH. A preliminary clinical trial comparing split treatments to the face and hand with autologous fat grafting and Platelet-Rich Plasma (PRP): a 3D, IRB-approved study. Aesthet Surg J. 2019;39 (6):675-686. doi:10.1093/asj/sjy254

31. Modarressi A. Platelet Rich Plasma (PRP) improves fat grafting outcomes. World J Plast Surg. 2013;2(1):6-13.

32. Ali YH. Two years' outcome of thread lifting with absorbable barbed PDO threads: innovative score for objective and subjective assessment. J Cosmet Laser Ther. 2018;20(1):41-49. doi:10.1080/ 14764172.2017.1368562

33. Anitua E, Sanchez M, De la Fuente M, Zalduendo MM, Orive G. Plasma rich in growth factors (PRGF-Endoret) stimulates tendon and synovial fibroblasts migration and improves the biological properties of hyaluronic acid. Knee Surg Sports Traumatol Arthrosc. 2012;20 (9):1657-1665. doi:10.1007/s00167-011-1697-4

34. Anitua E, Sánchez M, Nurden AT, et al. Platelet-released growth factors enhance the secretion of hyaluronic acid and induce hepatocyte growth factor production by synovial fibroblasts from arthritic patients. Rheumatology (Oxford). 2007;46(12):1769-1772. doi:10.1093/rheumatology/kem 234

35. Ulusal BG. Platelet-rich plasma and hyaluronic acid - an efficient biostimulation method for face rejuvenation. J Cosmet Dermatol. 2017;16(1):112-119. doi:10.1111/jocd.12271

36. Kamakura T, Kataoka J, Maeda K, et al. Platelet-rich plasma with basic fibroblast growth factor for treatment of wrinkles and depressed areas of the skin. Plast Reconstr Surg. 2015;136(5):931-939. doi:10.1097/PRS.0000000000001705

37. Abdel-Maguid EM, Awad SM, Hassan YS, El-Mokhtar MA, ELDeek HE, Mekkawy MM. Efficacy of stem cell-conditioned medium vs. platelet-rich plasma as an adjuvant to ablative fractional $\mathrm{CO}_{2}$ laser resurfacing for atrophic post-acne scars: a split-face clinical trial. J Dermatol Treat. 2021;32(2):242-249. doi:10.1080/ 09546634.2019.1630701

38. Chandrashekar B, Nandini A. Acne scar subcision. J Cutan Aesthet Surg. 2010;3(2):125-126. doi:10.4103/0974-2077.69029

39. Deshmukh NS, Belgaumkar VA. Platelet-rich plasma augments subcision in atrophic acne scars: a split-face comparative study. Dermatol Surg. 2018. doi:10.1097/DSS.0000000000001614

40. Weibrich G, Kleis WKG, Hafner G. Growth factor levels in the platelet-rich plasma produced by 2 different methods: curasan-type PRP kit versus PCCS PRP system. Int J Oral Maxillofac Implants. 2002;17(2):184-190.

41. Landesberg R, Roy M, Glickman RS. Quantification of growth factor levels using a simplified method of platelet-rich plasma gel preparation. J Oral Maxillofac Surg. 2000;58(3):297-300; discussion 300-301. doi:10.1016/s0278-2391(00)90058-2

42. Li ZJ, Choi H-I, Choi D-K, et al. Autologous platelet-rich plasma: a potential therapeutic tool for promoting hair growth. Dermatol Surg. 2012;38(7):1040-1046. doi:10.1111/j.1524-4725.2012.02394. $\mathrm{X}$

43. Uebel CO, da Silva JB, Cantarelli D, Martins P. The role of platelet plasma growth factors in male pattern baldness surgery. Plast Reconstr Surg. 2006;118(6):1458-1466; discussion 1467. doi:10.1097/01.prs.0000239560.29172.33

44. Yuksel EP, Sahin G, Aydin F, Senturk N, Turanli AY. Evaluation of effects of platelet-rich plasma on human facial skin. J Cosmet Laser Ther. 2014;16(5):206-208. doi:10.3109/ 14764172.2014.949274

45. Mishra A, Harmon K, Woodall J, Vieira A. Sports medicine applications of platelet rich plasma. Curr Pharm Biotechnol. 2012;13 (7):1185-1195. doi:10.2174/138920112800624283

46. Mautner K, Malanga GA, Smith J, et al. A call for a standard classification system for future biologic research: the rationale for new PRP nomenclature. PM\&R. 2015;7(4):S53-S59. doi:10.1016/j. pmrj.2015.02.005 
47. DeLong JM, Russell RP, Mazzocca AD. Platelet-rich plasma: the PAW classification system. Arthroscopy. 2012;28(7):998-1009. doi:10.1016/j.arthro.2012.04.148

48. Hausauer AK, Humphrey S. The physician's guide to platelet-rich plasma in dermatologic surgery part I: definitions, mechanisms of action, and technical specifications. Dermatol Surg. 2020;46 (3):348-357. doi:10.1097/DSS.0000000000002147

49. Hausauer AK, Humphrey S. The physician's guide to platelet-rich plasma in dermatologic surgery part II: clinical evidence. Dermatol Surg. 2020;46(4):447-456. doi:10.1097/DSS.0000000000002148

50. Lee Z-H, Sinno S, Poudrier G, et al. Platelet rich plasma for photodamaged skin: a pilot study. J Cosmet Dermatol. 2018. doi:10.1111/ jocd. 12676

51. Cameli N, Mariano M, Cordone I, Abril E, Masi S, Foddai ML. Autologous pure platelet-rich plasma dermal injections for facial skin rejuvenation: clinical, instrumental, and flow cytometry assessment. Dermatol Surg. 2017;43(6):826-835. doi:10.1097/ DSS.0000000000001083

52. Abuaf OK, Yildiz H, Baloglu H, Bilgili ME, Simsek HA, Dogan B. Histologic evidence of new collagen formulation using platelet rich plasma in skin rejuvenation: a prospective controlled clinical study. Ann Dermatol. 2016;28(6):718. doi:10.5021/ad.2016.28.6.718

53. Elnehrawy NY, Ibrahim ZA, Eltoukhy AM, Nagy HM. Assessment of the efficacy and safety of single platelet-rich plasma injection on different types and grades of facial wrinkles. J Cosmet Dermatol. 2017;16(1):103-111. doi:10.1111/jocd.12258

54. Gordon R. Platelet-rich growth factor for lip and perioral rejuvenation. a case study on "the kiss shot". Dent Today. 2016;35(5):114, 116.
55. Mehryan P, Zartab H, Rajabi A, Pazhoohi N, Firooz A. Assessment of efficacy of platelet-rich plasma (PRP) on infraorbital dark circles and crow's feet wrinkles. J Cosmet Dermatol. 2014;13(1):72-78. doi:10.1111/jocd.12072

56. Kang BK, Shin MK, Lee JH, Kim NI. Effects of platelet-rich plasma on wrinkles and skin tone in Asian lower eyelid skin: preliminary results from a prospective, randomised, split-face trial. Eur J Dermatol. 2014;1-2(1):100-101. doi:10.1684/ejd.2014.2267

57. Redaelli A, Romano D, Marcianó A. Face and neck revitalization with platelet-rich plasma (PRP): clinical outcome in a series of 23 consecutively treated patients. J Drugs Dermatol. 2010;9 (5):466-472.

58. Sevilla G, Dhrat R, Shetty G, Kadam P, Totey S. Safety and efficacy of growth factor concentrate in the treatment of nasolabial fold correction: split face pilot study. Indian J Dermatol. 2015;60 (5):520. doi:10.4103/0019-5154.159628

59. van Dongen JA, Boxtel JV, Willemsen JC, et al. The addition of tissue stromal vascular fraction to platelet-rich plasma supplemented lipofilling does not improve facial skin quality: a prospective randomized clinical trial. Aesthet Surg J. 2021;sjab109. doi:10.1093/asj/ sjab109

60. Moher D, Liberati A, Altman D, Tetzlaff J, et al. The PRISMA statement for reporting systematic reviews and meta-analyses of studies that evaluate health care interventions: explanation and elaboration. Journal of clinical epidemiology. 2009;62(10)

\section{Publish your work in this journal}

Clinical, Cosmetic and Investigational Dermatology is an international, peer-reviewed, open access, online journal that focuses on the latest clinical and experimental research in all aspects of skin disease and cosmetic interventions. This journal is indexed on CAS.
The manuscript management system is completely online and includes a very quick and fair peer-review system, which is all easy to use. Visit http://www.dovepress.com/testimonials.php to read real quotes from published authors. 